\title{
A LIBERDADE DE ASSOCIAÇÃO E DE REUNIÃO ${ }^{1}$
}

\author{
FREEDOM OF ASSOCIATION AND OF REUNION
}

MARCO RUOTOLO ${ }^{2}$

\begin{abstract}
RESUMO: Este artigo versa sobre a questão da liberdade de associação e de reunião, abordando os seus limites subjetivos e objetivos, além dos seus marcos históricos, com maior destaque ao Ordenamento Jurídico Italiano, e a respectiva tutela jurisdicional. Nesse sentido, discorre sobre a legalidade do aviso prévio para manifestações, bem como analisa o tema da justiça endoassociativa; das associações secretas e paramilitares, e por fim, aborda a promoção do associacionismo e a sua constitucionalidade.

PALAVRAS-CHAVE: Liberdade de Associação; Liberdade de Reunião; Aviso Prévio; Pluralismo; Limites Constitucionais Italianos; Justiça Endoassociativa; Associacionismo.
\end{abstract}

ABSTRACT: This article discusses the issue of freedom of association and assembly, approaching its limits subjective and objective, beyond its historical landmarks, most notably the Italian legal system, and its remedy. In this sense, is about the legality of the notice to events, and analyzes the theme of endo-associative justice; Secret and paramilitary associations, and finally addresses the promotion of associations and their constitutionality.

KEYWORDS: Freedom of Association; Freedom of Assembly; Warning; Pluralism; Italian Constitutional Limits; Endo-associative Justice; Associationism.

SUMÁRIO: 1. Notas Históricas sobre a Liberdade de Reunião; 2. A Liberdade de Reunião na Constituição Republicana; 3. Os Limites Subjetivos à Liberdade de Reunião; 4. Os Limites Objetivos da Liberdade de Reunião; 5. A Natureza Jurídica do Aviso Prévio; 6. O Problema da Tutela Jurisdicional da Liberdade de Reunião; 7. Notas Históricas sobre a Liberdade de Associação; 8. O Pluralismo dos Ordenamentos Sociais; 9. O Reconhecimento Constitucional; 10. Os Limites dos Fins Vetados pela Lei Criminal como Garantia da Liberdade de Associação; 11. A Referência apenas aos Cidadãos; 12. A Liberdade de Associação e o Problema da Justiça Endoassociativa; 13. A Proibição das Sociedades Secretas e Paramilitares; 14. A Promoção do Associacionismo; Referências Bibliográficas.

Artigo recebido em 09.01.2013. Artigo aceito para publicação em 23.06.2013 mediante convite.

${ }^{1}$ Artigo publicado em I Diritti Costituzionali, vol. II, Torino, Giappichelli, 2006, p. 682-726, traduzido da língua italiana por Camila Herzog Koch, Mestranda em Direito pela PUCRS.

${ }^{2}$ Professor de Direito Constitucional da Universidade Roma Tre, Itália. 
SUMMARY: 1 . Historical Notes on Freedom of Assembly; 2. The Freedom of Assembly in the Republican Constitution; 3. The Subjective Limits of Freedom of Assembly; 4. The Objective Limits of Freedom of Assembly; 5 . The Nature of the Legal Notice; 6 . The Problem of Judicial Protection of Freedom of Assembly; 7. Historical Notes on Freedom of Association; 8. The Pluralism of the Social Orders; 9. The Constitutional Recognition; 10. The Limit of the Prohibitive Effects on Individuals by Criminal Law as a Guarantee of Freedom of Association; 11. The Reference Only to Citizens; 12 . The Association and Freedom in the Problem of Endo-associative Justice; 13. The Prohibition of Secret Societies and Paramilitary Forces; 14 . The Promotion of Associations; References.

\section{NOTAS HISTÓRICAS SOBRE A LIBERDADE DE REUNIÃO}

Nas democracias pluralistas, a Constituição não regula apenas as principais posições abstratas do privado em relação à autoridade pública, mas tende $a$ organizar a liberdade humana na realidade social ${ }^{3}$. Não se limita mais a proteger o privado do poder, numa lógica de separação, mas propõe-se a permitir o estabelecimento de uma relação dialética com o poder, em uma dimensão democrático-participativa que não se exaure no direito do status activus civitatis, isto é, essencialmente, no direito eleitoral ativo e passivo.

Para ser relevante, neste contexto, e acima de tudo uma vocação -públicade certos direitos (reunião, associação, em especial de partidos políticos e manifestação de pensamento), considerado juntamente com as garantias do pluralismo político e sindicais, não só os fatores essenciais da formação da opinião pública democrática, mas também a formação de instrumento de participação política, o processo político se dá, pelo menos em parte, em sociedade ${ }^{4}$. Os direitos, portanto, cujo exercício podem ser realizados por competição na participação política que pode, também, ser atribuída a uma leitura integrada do princípio pluralista e do princípio da igualdade, entendidos como os pilares de uma sociedade aberta que torna possível (por meio de processos de "comunicação") a realização de identidades múltiplas ${ }^{5}$.

E, pela necessidade de atender à demanda, por ampliação da participação política que se inscreve, historicamente, a consolidação progressiva do direito de reunião, que iremos analisar. Um direito que, como veremos, não está limitado exclusivamente dentro da esfera política, encontra-se vinculado com a sociabilidade intrínseca dos seres humanos.

Que os homens têm o direito de se reunir para tratar dos seus assuntos, para comunicar reciprocamente suas idéias, para desfrutar em comunidade prazeres e diversões, e o princípio que não precisa, para ser demonstrado, de toda a imensa quantidade de volume de panfletos, de discursos, de declamações enviadas por escrito ou repetidas a partir das tribunas durante um século ou mais, - se não tivesse ficado muito evidente a

\footnotetext{
${ }^{3} \mathrm{~V}$. abaixo, item 8, para recordar a definição helleriana.

${ }^{4}$ RIDOLA, Libertà e Diritti nello Sviluppo Storico del Costituzionalismo, publicado no Vol. I.

${ }^{5}$ RIDOLA, op. cit.
} 
necessidade de tomar as ruas com armas na mão, para conquistar ou manter inviolável. A nossa natureza humana, vive em sociedade, dotada de expressão, necessária para atender ao socorro moral e material, em quase todos os passos que movemos; os fatos da família, da cidade, do Estado, existente como lei inevitável ao progresso da humanidade, tudo isto, para não dizer mais, demonstra a forma superiora de reunir todo o raciocínio, do que o necessário, para o direito natural. Pretende-se mostrar realmente que o homem tem esse direito, sendo apropriado demonstrar que ele tem direito de viver em sociedade. Atualmente, viver em sociedade é inevitável: o homem, dizia o filósofo Aristóteles, é um animal social' ${ }^{6}$.

A história e os fundamentos do direito de reunião são brilhantemente expressas na faixa de abertura da voz anônima da Reunione della Nueva Enciclopedia Populare Italiana acima referida. É a história que ciclicamente propõe o reconhecimento e a renúncia, ao menos substancial, desse direito. Um direito, vinculado às necessidades respectivas da natureza sociável do homem, que exigia, em alguns momentos, tomar as ruas com as armas nas mãos para conquistá-la ou mantê-la inviolada.

Então, sabemos a importância que tiveram na Grécia e em Roma os discursos, face ao impacto das audiências públicas convocadas pelos grandes oradores populares, mas também sabemos que a Roma Imperial, contava com leis que restringiam o direito de reunião: o crime de majestade de se reunir armado e loca occupare vel templa ${ }^{7}$, e se pretendiam armados non utique qui tela haberent, sed etiam quid aliud, quod nocere postest ${ }^{8}$. Após a queda do Império a situação não mudou substancialmente, nos vários Estados, as reuniões por um longo tempo, não eram nem permitidas, nem proibidas.

Entre as primeiras leis a este respeito, há aquelas que proibiam as reuniões para fins religiosos, que marcaram a abertura de uma fase mais ampla sobre o fenômeno das reuniões, caracterizado pela prevalência de medidas preventivas. Pelo menos até a Revolução de 1789, que - inaugurou o mundo em uma nova forma - definitivamente empurrando o poder público a um reconhecimento generalizado do direito de reunião ${ }^{9}$. O reconhecimento constitucional do direito de reunião no moderno ordenamento estatal resulta intimamente com a importância dada à vocação política, do direito e a necessidade, cada vez mais sentida, de abrir uma nova fase na dialética entre os cidadãos e o poder político.

É fácil entender, então, como o progressivo aumento da liberdade de reunião aparece ligado ao processo de ascensão ao poder das revoluções burguesas, seja no momento da revolução do século XVIII, seja na época das Constituições Ottriate do século XIX. Já em 1789, uma primeira alteração à

\footnotetext{
${ }^{6}$ V. Riunione (diritto), em Nuova Enciclopédia Popolare Italiana, Torino XIX, 1864, 654.

${ }^{7}$ Lei $\mathrm{n}^{\circ} 1$, § $1^{\circ}$, Dig. XLVIII, 4.

${ }^{8}$ Lei no 9, Dig, XLVIII, 6.

${ }^{9} \mathrm{~V}$. Riunione (diritto di), cit., 655.
} 
Constituição Federal dos Estados Unidos da América previa que o congresso não poderia restringir o direito das pessoas de se reunir e encaminhar petições ao governo. $\mathrm{E}$, ainda, poderiam ser enviadas às autoridades públicas às petições que se referissem ao reconhecimento da liberdade de reunião, desde que ocorresse de forma pacífica e sem armas, estipuladas pela França com a Lei de 18 de dezembro de 1789.

Mas tal atitude de abertura continuou, vez que concluído o processo de chegada ao poder da burguesia, contra o enrijecimento do livre exercício do seu direito de reunião como instrumentos constitutivos da principal luta política, por meio do qual era possível expressar as forças do anti-sistema.

Não surpreende, portanto, que na própria França, onde, após a Revolução de 1789 , foi reconhecido o direito dos cidadãos de se reunirem pacificamente, e formarem sociedades livres, em conformidades com as leis do Estado ${ }^{10}$, a Constituição de 1791, especificamente, já exigia a observância das leis da polícia. Limites mais rigorosos para o exercício desse direito foram previstos pela Constituição de 1795, que proibia, entre outras coisas, que as assembleias de cidadãos se denominassem populares, assim como no Código Penal de 1810.

Igualmente, após a Revolução de 1848, a Constituição de 4 de novembro do mesmo ano, reconheceu, outra vez, o direito de se reunir pacificamente e sem armas, excepcionando com relação aos direitos e liberdades dos outros cidadãos, e preservando a segurança pública. E, em nome da segurança pública, um Decreto, de 25 de março de 1852, sujeitava às reuniões aos requisitos do Código Penal e da Lei de 10 de abril de 1834, para as associações, que aumentava a sanção e ditava regras específicas destinadas a prevenir a evasão do Código Penal. Ficando, portanto, estendida uma disciplina restritiva do Código Penal e, em particular, a previsão para que qualquer associação de mais de vinte pessoas, cujo objetivo fosse se reunir durante todo o dia ou num determinado dia, para tratar de assuntos religiosos, literários, políticos ou outros, não poderia se formar sem o consentimento do governo, as quais foram deixadas em aberto para impor condições que entendessem oportunas.

Sobre esse assunto, é também emblemática a experiência italiana da época estatutária. O direito de reunião foi reconhecido pelo Estatuto Albertine da seguinte forma: é reconhecido o direito de se reunir pacificamente e sem armas, e em conformidade com as leis que possam regular o exercício do interesse público. Essa disposição não se aplica às reuniões em locais públicos ou abertos ao público, que permanecem inteiramente submetidas às leis da polícia (art. 32).

O Decreto Régio $n^{\circ} 798$, de 30 de setembro de 1848 , no art. 798 , estabelecia que os oficiais de segurança pública tinham o direito de intervir em cada reunião e de ordenar a dissolução, se por qualquer razão pudesse ser

\footnotetext{
${ }^{10}$ Decreto da Assembléia Nacional de 13 novembro de 1790.
} 
perturbada a ordem pública. Os indivíduos reunidos poderiam ser recolhidos na primeira intimação que Ihes fosse feita pelo oficial de segurança pública, na omissão era autorizado o uso da força ${ }^{11}$. A única forma de intervenção repressiva, no interesse da ordem pública também é relatada na alínea $b$, da Lei $n^{\circ} 2.248$, de 20 de março de 1865, sobre a segurança pública, para, em seguida, implementar, sem restrições, as propostas concretas do Ministro Peruzzi sobre a obrigatoriedade da notificação prévia e o poder de proibição preventivo.

O único limite ao exercício do direito de reunião parecia ser na obrigação de se reunir pacificamente e sem armas, com a restrição estabelecida pela legislação de segurança pública, o respeito pelo ordenamento público para reuniões em locais públicos ou abertos ao público. Mas, na realidade, o governo avocou o direito de sempre poder proibir preventivamente reuniões e encontros, embora essa prerrogativa não fosse legislativamente atribuída ${ }^{12}$, reportando-se ao poder geral de prevenir delitos previstos na alínea $b$, do art. 9 da Lei $n^{\circ} 2.248 / 1865$.

Assim, nas restrições introduzidas pelo novo texto consolidado das leis sobre segurança pública, promovidas por Crispi (Decreto Régio, de 30 de junho de $1889, \mathrm{n}^{\circ} 6144$ ), não foram formalizados os poderes de fato exercidos pelas autoridades públicas. $O$ artigo $1^{\circ}$ da Lei de Segurança de 1889 introduziu o instituto do aviso prévio enviado à autoridade de segurança pública. A obrigatoriedade de aviso prévio atinentes às reuniões públicas deveria ser cumprida, pelo menos, 24 horas antes de sua execução.

Também foi previsto para o poder público a faculdade de dissolver a reunião por falta de notificação, tanto para a hipótese de formação de comissão que abordassem crimes punidos no Código Penal e pela presença de "gritos sediciosos e manifestações" contra "os poderes do Estado e contra os chefes de governos estrangeiros e seus representantes."

Além disso, a própria noção de reunião "pública", que se referiam principalmente às limitações acima, recebeu uma nova prorrogação como resultado da Circular Rudinì, de 06 de abril de 1896, $n^{\circ} 3751$, pois estas reuniões públicas eram consideradas para locais designados, o número de pessoas convidadas, o propósito e o tema a ser tratado na reunião.

À autoridade policial foi dado um controle total e direto sobre a exigência do aviso prévio que resultou na anulação do exercício da liberdade de reunião, de fato sujeita à autorização prévia. E quando os "normais" meios de repressão fornecidos pelas leis de segurança pública não eram suficientes, eles invocavam a "lei suprema da saúde pública" para justificar proibições,

\footnotetext{
${ }^{11}$ Sucessivamente, com Rattazzi, 13 de novembro de 1859, $\mathrm{n}^{\circ} 3720$, art 80, foi prevista a possibilidade do uso da força como recurso, somente após três distintas formas de intimação, cada uma delas deveria ser precedida de um rufar de tambores ou de um trompete.

${ }^{12}$ V. MUSSO, Brevi note sulla Libertà di Riunione in Italia tra la fine dell'ootocento e l'inizio del Novecento, in Scritti in onore di C. Mortati, I, Milão 1977, 754 ss.
} 
geralmente, se fazia o uso de leis gerais ou especiais "temporárias" (18941898), que suspendiam por tempo prolongado a liberdade de reunião ${ }^{13}$.

O regime essencialmente iliberal que vinha sendo formado no final de 1800 e no início de 1900, que havia encontrado expressão significativa na legislação Crispiniana, foi preservado e intensificado no período fascista, já na primeira lei fascista de segurança pública ${ }^{14}$.

O aviso prévio deveria ser feito, pelo menos, três dias antes da realização da reunião e com a observância das proibições relacionadas com "manifestações ou gritos sediciosos", e com acréscimos, "ou lesiva ao prestígio de autoridade, ou que pudesse pôr em perigo a ordem pública" (art. 20), indicando, ainda, que o evento seria sempre considerado sedicioso quando houvesse a exposição de "bandeiras ou emblemas que são símbolos da subversão social ou rebelião ou insulto ao Estado, ao Governo ou às autoridades" e de "insígnias de associações facciosas". Assim, enriqueceu-se a estrutura de um regime autoritário para prevenção de qualquer possível manifestação hostil contra o governo ${ }^{15}$.

\section{A LIBERDADE DE REUNIÃO NA CONSTITUIÇÃO REPUBLICANA}

Com o advento do ordenamento republicano, a liberdade de reunião tornou, finalmente, a ser garantida. O artigo 17 da Constituição Italiana reconheceu, de fato, aos cidadãos o direito de se reunir pacificamente e sem armas, e dispôs que para reuniões em lugar público deveria ser dado aviso prévio à autoridade, que poderia proibi-las por comprovado motivo de segurança ou de incolumidade pública. Nos casos, as reuniões de coexistência voluntária de mais pessoas, em um mesmo lugar, por prévio acordo entre os participantes ou a convite dos promotores, a fim de satisfazer um interesse comum. A fórmula "mesmo local" não teria de informar a identificação de um lugar específico, mas seria usada para indicar a proximidade da matéria entre as pessoas interessadas em se reunir ${ }^{16}$.

O plurisubjetivismo e o propósito comum, por outro lado, são características relativas também nas associações das quais a reunião essencialmente se diferencia pela ausência do vínculo de ideais que decorrem entre os parceiros. E, acredita-se ser uma consequência da existência de um vínculo meramente físico e material intermediário entre as pessoas reunidas com o fato que as reúnem, tanto intenso quanto instável, ou melhor, que a duração é meramente acidental (ao contrário da "associação"), e não ocasional (caso contrário não haveria encontro). A reunião é diferente, pois um encontro pode ser definido como efêmero, improvisado, casual de conjunto de pessoas ${ }^{17}$, que se realiza quando mais pessoas, apenas por acaso e sem qualquer

\footnotetext{
${ }^{13}$ V. MUSSO, op. cit., 790 ss. Pace, La Libertà di Reunione, in La Pubblica Sicurezza, a cura di Barile, Vicenza 1967, 239 ss.

${ }^{14} \mathrm{~N}^{0} 1848$, de 26 nov 1926.

${ }^{15}$ Ver também Decreto Régio de 18 de junho, 1931, no 773.

${ }^{16}$ PACE, La Libertà di Riunione nella Costituzione Italiana.

${ }^{17}$ BARILE, Assembramento, in Enc. Dir., III, Milano, 1958, 405.
} 
consulta $^{18}$, estão no mesmo lugar público e agrupados, atraídos por alguma circunstância inesperada ou qualquer chamada oratória de improviso, eventos em que todos os presentes dedicam a sua atenção, juntamente com a de outras pessoas presentes ${ }^{19}$.

Sobre esse último ponto, é necessário um esclarecimento. Apenas quando a presença física dos sujeitos não for mais voluntária, ou seja, no sentido de não nascer da consciência e da determinação de atuar, e manter uma posição que permita o exercício de formas de interação social ${ }^{20}$, podemos excluir a aplicação da disciplina que trata o art. 17 da Constituição ${ }^{21}$. Se, no entanto, a vontade de estar fisicamente juntos surge espontaneamente, mesmo sem que tenha havido uma consulta formal.

Deve-se concluir, tal manifestação de interação social entre aqueles que a implementaram, dentro do gênero da reunião. Neste último caso, apesar da impossibilidade material do aviso prévio, como veremos, não constitui uma condição jurídica para a existência de reunião em local público, aplicando, portanto, as garantias previstas pelo art. 17 .

$\mathrm{O}$ art. 17 da Constituição Italiana disciplina o direito de reunião e da conduta pacífica, e não se preocupa em determinar quais as finalidades das atividades exercidas ${ }^{22}$, configurando-se a liberdade de reunião como direito instrumental, em comparação com outras liberdades, como, por exemplo, a liberdade de expressão ou de associação. Mas, tal instrumentalidade recorrente na maioria dos casos, não é, na opinião de alguns escritores, o elemento caracterizante do direito de reunião. A indiferença em relação ao fim da reunião, permitiria-Ihes para explicar como o último tem direito a uma garantia constitucional, mesmo quando lhes falta um objetivo comum ${ }^{23}$.

De acordo com o Mezzanotte, o art. 17 da Constituição tutelaria apenas a voluntária co-presença física considerada por si só, como sendo um "valor" presente quando cada uma das partes pretende realizar um propósito autônomo e distinto dos outros, ou não pretendem prosseguir algum fim ${ }^{24}$. No entanto, a conotação de reunião como um direito não necessariamente instrumental não seria excludente da centralidade desse direito em relação às outras liberdades que, em um certo sentido, contém em embrião, apesar dos progressos tecnológicos conduz a um afastamento da dimensão comunitária participativa da existência, fazendo com que pareça para nós a afirmação de

\footnotetext{
${ }^{18}$ RANELLETTI, La Polizia di Sicurezza, in Primo Trattato completo di Diritto Amministrativo Italiano, diretto da V.E. Orlando, IV,1 Milão, 1904, 489.

${ }^{19}$ BARILE, op. cit., 405.

${ }^{20}$ BORRELLO, Riunione (diritto di), in Enc. dir., XL, Milano 1989, 1415.

${ }^{21}$ Pensemos, por exemplo, em uma fila diante de uma porta, ou uma multidão de curiosos antes de algum evento especial.

${ }_{22}$ PACE, Problematica delle Liberta Costituzionali, Parte Speciale, II ed., Padova 1992, 303.

${ }^{23}$ MEZZANOTTE, La Riunione nella Dinamica del Fenomeno Associativo e come Valore Costituzionale «autonomo», in Giur. cost., 1970, 616.

${ }^{24}$ MEZZANOTTE, loc. cit.
} 
que agora sem o direito de reunião, a associação não se forma, a coalizão é sem sentido, a palavra não é o que se ouve, o direito eleitoral torna-se uma farsa, as entidades representativas deixarão de existir ${ }^{25}$, afirmando essa última que poderia ser enquadrado em uma corrente de pensamento, seguida entre os constitucionalistas italianos do séc. XIV, que constituía a reunião como um meio de formação de opinião pública ${ }^{26}$, bem como na tendência mais ampla para o reconhecimento constitucional do direito de reunião, como uma resposta à expansão da participação política ${ }^{27}$.

Nesse horizonte da constituição republicana, a liberdade de reunião, no entanto, não se limitava, exclusivamente, dentro da "esfera política", estando este direito ligado à intrínseca sociabilidade dos seres humanos, que envolva todos os momentos da vida cotidiana ${ }^{28}$. O fenômeno da reunião não se aplica apenas à manifestação e à comunicação do pensamento, mas é estendido a todos as formas de interação social viabilizada pela situação material criada pela proximidade física de uma pluralidade de indivíduos ${ }^{29}$, como, por exemplo, para a realização em conjunto de atividades esportivas, entretenimento, trabalho, e não estritamente relacionadas com a difusão de pensamentos ${ }^{30}$ podem, mais genericamente, englobar todas as atividades que são uma expressão do direito de qualquer pessoa de estar fisicamente com outros encontros, procissões (como reuniões religiosas em movimento), marchas (como em reuniões de movimento civis), comícios, meetings, sit-in, assembleias, etc. ${ }^{31}$

Atualmente, a própria adesão da tese que trata o art. 17 assegura que todas as agregações físicas de pessoas no mesmo lugar por um determinado período de tempo, através do qual são implementadas formas de interação entre as pessoas participantes, com a importante especificação, de modo que a identidade do lugar é puramente relativa aos sujeitos reunidos, e que permanecem reunidos fisicamente no mesmo lugar tanto se permanecem parados ou se movimentam ${ }^{32}$, induz ainda mais a reflexão. Dúvidas em particular podem ser manifestadas sobre as supostas consequências que essa tese, estabeleceria por meio do art. 17 a não garantia das reuniões caracterizada por pessoas singulares, de bicicleta, motocicleta, automóveis, caminhões, tratores, carruagens a cavalo e etc ${ }^{33}$.

Embora, compreendendo as razões pelas quais se defende a necessidade de evitar dilatações das garantias do art. 17, não parece que o uso de meios

\footnotetext{
${ }^{25}$ Como indicado no artigo que apareceu na Critica Sociale, 1860, relatado por Musso, Brevi note, cit., 754.

${ }^{26}$ Se não como órgão dessa: v. MINGUZZI, La Teoria Opinione Pubblica nello Stato Costituzionale, Bologna 1887,35 ss.

${ }^{27}$ Ver acima, item 1.

${ }^{28}$ PACE, Problema de Libertei Constitucional, cit., 300.

${ }^{29}$ BORRELLO, op. Cit., 1401.

${ }^{30}$ Ver PACE, op. ult cit., 300 e jurisprudência já citada.

${ }^{31}$ V. Prisco, Riunione (libertà di), em Enc. giur. XVII, Roma 1991, 4.

${ }^{32}$ PACE, Problematica delle Libertà Costituzionali, cit., 306 e 307.

${ }^{33}$ Então, ao inverso PACE, loc. cit.; ID., La Libertà di Riunione nella Costituzione Italiana, cit., 45.
} 
de transporte por uma pluralidade de pessoas que desejam voluntariamente estarem simultaneamente presentes implica em si na recompreensão de tal fenômeno fora do gênero reunião. A possível aplicação dessa disciplina constitucional do direito de reunião na hipótese supramencionada, não exclui da tutela também as circunstâncias subjetivas que as unem, em particular, ao direito de circular livremente (artigo 16 da Constituição), de modo que poderia ser considerado legítima uma disciplina legislativa diferenciada e restritiva que operassem um equilíbrio entre os interesses contrapostos, ambos constitucionalmente protegidos. Em outras palavras, nesses casos, também se aplicaria o art. 16, também, e não apenas.

Além disso, na ausência de uma disciplina legislativa específica, tratando-se de reunião em local público, para as quais se faz necessário o aviso prévio, a autoridade pública poderia dispor de alterações no procedimento sobre a sua hora e local designado, na medida em que é constitucionalmente justificado pelas necessidades da circulação e não resultaria em arbitrária, mas entendida como limitadora do direito de reunião. Não diversamente pode acontecer com relação às reuniões em locais públicos de pessoas, que não usam meios de locomoção ou de similares.

Mas, fora de tais exigências, não parece oportuno operar uma problemática, e, potencialmente arbitrária, distinção sobre a emergência ou ao menos a explanação exterior da pessoa humana, fundada na natureza do meio utilizado com o fim de reconquistar os fenômenos individuais no gênero 'reunião'. Não parece, por motivos análogos, que para as competições esportivas, com a utilização de meios artificiais, seria descartada em termos gerais a aplicação de garantias próprias da liberdade de reunião ou que deveriam ser limitadas aos espectadores que estão assistindo.

Para sustentar a tese contrária, vem se adotando outro argumento válido também para os casos em que não há a utilização de meios artificiais para competir, de modo que, por exemplo, nas competições de caminhada os participantes tendem a se separar mais do que se agregar, sendo a forma para eles alcançarem a vitória pessoal, embora exista uma vontade geral de se manter próximo, pelo menos no contexto mais amplo da pista de competição ${ }^{34}$.

Poderia-se, ao invés de reprimir também as competições de corridas, e mais genericamente, os esportes chamados individuais pois há a vontade de estarem presentes juntamente em um mesmo local que caracteriza a reunião, não importando que o fim da modalidade prevista seja a competição. Só se a competição acontecer em um local destinado ao transporte público, ficaria em jogo, também, o direito de terceiros de circularem livremente, o que poderia legitimar, por exemplo, a modificação do percurso, a fim de conciliar as diferentes necessidades. E, parece possível chegar às mesmas conclusões a respeito dos passeios ciclísticos, em relação ao previsto para os ciclistas fora dos centros

\footnotetext{
${ }^{34}$ Ver PACE, Problematica delle Libertà Costituzionale, cit., 307; bem como, Problematicamente, Borrell, Reunião, já referido, 1412.
} 
habitados, que devem sempre permanecer uma única fila ${ }^{35}$, não se descartando a possibilidade de compreender os passeios ciclísticos no gênero reunião ${ }^{36}$.

Se porventura, essa disposição visa garantir que a liberdade de manifestação da pessoa não impeça a liberdade dos outros de circulação, fazendo um justo equilíbrio entre os requisitos potencialmente conflitantes e respondendo à necessidade de uma regulamentação adequada de circulação, aplicável, também, no caso de excursões turísticas, dessa forma, as reuniões realizadas entre amigos, não precisariam de aviso prévio e relativamente não poderiam ser invocadas a dissolução como consequência da omissão do aviso prévio que, como veremos em seguida, não constitui condição legal da existência de uma reunião, mas é principalmente destinada a facilitar as autoridades públicas na avaliação dos interesses potencialmente conflitantes.

De fato, pode-se argumentar que para tais reuniões, ao mesmo tempo realizadas em um local público, o aviso prévio não é necessário, entre aquelas que não constituem, ainda que distante perigo à segurança pública ${ }^{37}$.

Com maior razão, então, não se considera necessário o aviso prévio para os passeios de bicicleta fora da cidade, bem como compreende-se a necessidade de uma regra geral que, na ausência de oportunidade para as autoridades públicas de uma avaliação prévia dos interesses potencialmente em conflito, que regule os métodos de desempenho também no interesse da liberdade de movimento. O que é necessário, em geral, é detectar o propósito da tutela do art. 17 da Constituição e da voluntária co-presença física de mais pessoas no mesmo lugar, e não as atividades realizadas coletivamente. Essa última, quando envolvam interesses constitucionalmente tutelados, pode implicar em um equilíbrio entre as necessidades potencialmente em conflito que também pode resultar em um condicionamento do direito de reunião, sem que este fenômeno único de interação social deva ser colocado fora do gênero reunião, quase que todas as disposições constitucionais constituem entidade monádica, dotada de existência autônoma e excludente de aplicação de outras disposições constitucionais, ao invés de ser parte de um complexo sistema normativo.

Portanto, a previsão para o empreendedor que pretende organizar um entretenimento, em um lugar aberto ao público, deve obter uma licença do Chefe de polícia, e pode ser considerada inconstitucional, pois a reunião, nesse caso, envolve exercício da atividade empresarial, e como tal sujeita-se aos controles e aos programas referidos no art. 41 da Constituição. Por outro lado, para o entretenimento ser realizado em lugares abertos ao público, e não identificados para o exercício de atividades empresariais, a previsão da

\footnotetext{
${ }^{35}$ Art. 182, D.L. n' 285/1992.

${ }^{36}$ PACE, Violazione del la Libertà Sociale, Piuttosto, Restrizione Irrazionale della Libertà Individuale, in Giur. cost., 1998, 584, nº 4.

${ }^{37}$ PACE, sub art. 17, in Commentario della Costituzione, organizado por Branca, Bologna-Roma 1977,152 e 175.
} 
mesma obrigação (artigo 68 da Lei de Segurança Pública) é ilegítima, aplicando integralmente a disciplina do artigo 17 da Constituição ${ }^{38}$.

\section{OS LIMITES SUBJETIVOS À LIBERDADE DE REUNIÃO}

O direito de reunião garantido pelo artigo. 17 da Constituição é apenas para os cidadãos. Mas também pode ser estendido para os estrangeiros, cuja condição é regulamentada por lei, em conformidade com as normas e tratados internacionais ${ }^{39}$.

Nesse contexto, é importante agora fazer referência ao art. $2^{\circ}$ do Decreto-Lei $n^{\circ}$ 286, 25 julho de 1998, que marca a tendência de superação da condição de reciprocidade, enquanto o estrangeiro que resida legalmente no território do Estado goza dos direitos em matéria civil, atribuído a um cidadão italiano, a menos que as convenções internacionais em vigor e o presente texto disponham diversamente ${ }^{40}$. Os limites subjetivos do direito de reunião também derivam de legislação ordinária. Assim, não podem atender ao detento, limitado a "reuniões públicas", e alguém que passou por uma medida preventiva de vigilância especial ${ }^{41}$. É igualmente proibida a reunião que não seja de serviço nas instalações militares, e também fora desses lugares, assembleias ou encontros dos militares que se qualifiquem explicitamente como tal ou usem uniforme (artigo $7^{\circ}$ da Lei $n^{\circ} 382 / 1978$ ).

Em vez disso, podem se reunir para compor a organização da representação militar, das condições, nos limites e para os fins estabelecidos pela Lei $n^{\circ} 382 / 1978$. Essas limitações, bem como as penalidades para os promotores ou dos participantes nas reuniões arbitrárias dos militares nas instalações militares sem a autorização prévia (ver art. 184 , § $2^{\circ}$ do CPMP Codice Penale Militare di Pace) não foram consideradas inconstitucionais pelo Tribunal Constitucional (Sentenças 311/1982 e 24/1989) que sugeriu uma interpretação da disposição impugnada limitando a sua aplicabilidade às reuniões com características sediciosas ou rebeldes ${ }^{42}$.

Particularmente, é garantido o exercício do direito de reunião no local de trabalho (a chamada assembleia) o disposto no art. 20 Lei $n^{\circ} 300 / 1970$ e pelo art. 42, Decreto-Lei $n^{\circ} 165 / 2001$. Esse é configurado como um direito subjetivo em face do poder privado em confronto com o governo ${ }^{43}$, não sendo permitido

\footnotetext{
${ }^{38}$ Conforme o Tribunal Constitucional, Sentença nº 56/1970.

${ }^{39} \mathrm{~V}$. art.10, parágrafo $2^{\circ}$ da Constituição.

${ }^{40}$ Considera-se, também, que o Tribunal Constitucional parece ter reconhecido que as garantias relativas aos direitos fundamentais também se estendem aos estrangeiros, em resposta a esse efeito ao princípio da igualdade que a declaração refere-se especificamente apenas para "cidadãos": ver Sentença nº 62/1994, 219/1995, 509/2000, no ponto, no entanto, por favor consulte o item. 11 deste Capítulo.

${ }^{41}$ Artigo $5^{\circ}$ da Lei no 1423/1956, Tribunal Constitucional, Sentença n ${ }^{\text {os }}$ 27/1959, 105/1982 e $126 / 1983$.

${ }^{42}$ V. BALDUZZI, Principio di Legalita e Spirito Democratico nell'ordinamento delle Forze Armate, Milano 1988, 156 ss.; GARDINO CARLI, Riunione (liberta di), Torino 1997, 492.

${ }^{43}$ Assim BARBERA, Le Situazioni Soggettive. La Liberta dei Singoli. li Principio di Eguaglianza, in Manuale di Diritto Pubblico, organizado por Amato e Barbera, I, V ed., Bologna 1997, 293.
} 
ao empregador, mesmo que a reunião possa ser considerada privada, nenhum poder para conceder ou autorização (salvo quando a escolha de locais onde realizar uma reunião em questão) os seus poderes de participação $0^{44}$, tais garantias, mais fortes, se justificam à luz dos art. 41 , $\S 2^{\circ}{ }^{45}, 42, \S 2^{\circ}{ }^{46}$, bem como ao princípio da igualdade substancial (artigo $3, \S 2^{\circ}$ da Constituição).

\section{OS LIMITES OBJETIVOS DA LIBERDADE DE REUNIÃO}

$\mathrm{O}$ art. 17 da Constituição determina que as reuniões sejam conduzidas de forma pacífica e sem armas, e prevê a sujeição do aviso prévio, quando forem realizadas em um lugar público. A referência à tranquilidade (ou a falta de armas) é presente também em outras constituições europeias ${ }^{47}$ e se reflete na carta dos direitos fundamentais da União Europeia, que reconhece para cada pessoa o direito de liberdade de reunião pacífica e da liberdade de associação ${ }^{48}$.

De outra parte, tais limites são explicados em relação aos episódios verificados de violência que podem brotar da proximidade física de várias pessoas que constituem o fenômeno da reunião. Os limites para a liberdade de reunião, previsto pela Constituição Italiana, correspondem propriamente para atender as necessidades de graduação relacionadas aos diferentes perigos $^{49}$ de manifestações sociais de pessoas que se realizam por meio do exercício dessa ${ }^{50}$. O perigo é considerado possível pelo fato da simples presença de uma pluralidade de pessoas, em um lugar onde o acesso não seja regulado, ou seja, para reuniões em locais públicos nas quais o aviso prévio é necessário, por comprovado motivo de segurança ou de incolumidade pública, provavelmente, no caso da presença de armas, não seja possível remover a pessoa armada, legitima-se a dissolução da reunião, pela real hipótese de impacificidade.

A Constituição pressupõe a distinção tradicional entre reuniões privadas, reuniões abertas e reuniões públicas em locais públicos. As primeiras são reuniões as quais apensa podem ser acessados com o consentimento da pessoa que tem a disponibilidade jurídica do lugar, ou seja, o titular do ius admittendi (se pensa em uma reunião entre amigos, em uma casa particular). Nesse caso não é, obviamente, necessário aviso prévio, e também é garantida a liberdade de domicílio (artigo 14 da Constituição). Resultando que o impedimento desse dispositivo apenas em casos de consequências de

\footnotetext{
${ }^{44}$ V. também disciplina análoga art. 12 ss., D.I, 16 aprile 1994, nº 297.

${ }^{45}$ A iniciativa privada econômica não pode se desenvolver em contraste com a utilização social ou de modo que venha a causar dano à segurança, à liberdade e à dignidade humana.

${ }^{46}$ Que atribui à lei à tarefa de determinar os limites da propriedade privada com objetivo de assegurar a função social e de proporcionar a acessibilidade a todos.

${ }^{47}$ Por exemplo, artigo $8^{\circ}$ da Constituição Alemã, artigo 21 da Constituição Espanhola, art. 45 da Constituição Portuguesa, artigo 26 da Constituição Belga e artigo 79 da Constituição Dinamarquesa.

${ }^{48}$ Art. 12 corresponde, essencialmente, ao art. 11 CEDU, v. art. II-72 do Tratado que adota uma Constituição para a Europa, assinado em Roma, em 29 de outubro de 2004.

${ }^{49}$ Em comparação com o fim público material.

${ }^{50}$ PACE, Problematica delle Libertà Costituzionali, cit., 315.
} 
inspeção, buscas, apreensões ou medidas restritivas de liberdade pessoais tomadas para as inspeções ou buscas domiciliárias.

O impedimento de reunião em lugar não aberto ao público não poderia, portanto, estar determinado pelo mero fato de "colocar em perigo a ordem pública ou a segurança pública ${ }^{51}$, mas apenas pelos fatos que forem identificados pela prática de delitos pelos quais as leis penais disponham a obrigação ou, pelo menos, o poder de arresto ou detenção de uma das pessoas reunidas ${ }^{52}$.

Uma visão diferente têm aqueles que, ao aderir à tese de que para a reunião em lugar privado usufrui-se, também, da garantia da inviolabilidade do seu domicílio, acreditando-se que o limite próprio da pacificidade e do desarmamento, legitima a violação da casa "por razões de incolumidade e segurança", ou seja, fora dos casos previstos no artigo 14 da Constituição ${ }^{53}$. Mesmo para as reuniões em locais aberto ao público, em lugares no qual o acesso é permitido em certas condições (por exemplo, cinema, teatro, palco), não é necessário o aviso prévio (ao contrário do que aconteceu na época estatutária). Esta hipótese, portanto, pode legitimar eventual controle preventivo solicitado pelas autoridades públicas (ex.: segurança da construção do local em que será realizado um espetáculo), não se traduzindo em um mero pretexto para impedir a realização da reunião. As reuniões em locais públicos são aquelas que são realizadas em lugares os quais todos possam acessar livremente (por exemplo, uma praça) e, por isso é necessário o aviso prévio às autoridades competentes (pelo menos alguns dias antes, de acordo, com as disposições das Leis de Segurança Pública).

Portanto, as reuniões são geralmente tuteladas pela norma constitucional enquanto acontecem "pacificamente e sem armas", se não prejudicarem ordem pública material (ausência de violência física e de desordem), para reuniões em público se coloca o problema adicional da tutela da segurança e da incolumidade de terceiros, que não participam. Em vista de tal eventualidade, outra medida de dissolução que pode ser adotada em caso de violação da ordem material pública, é a possibilidade da proibição antecipada por comprovados motivos de segurança ou de incolumidade pública (artigo 17, parágrafo $3^{\circ}$ da Constituição). E, assume uma importância especial na previsão, por estas razões devem ser comprovados, o que traduz a necessidade de uma motivação exauriente, em relação à situação real, de eventual medida da autoridade de segurança pública, a fim de permitir uma união sobre o interesse das partes com pela autoridade judiciária ${ }^{54}$.

\footnotetext{
${ }^{51}$ Que fazem a dissolução possível das reuniões em locais públicos ou aberto ao público, nos termos da Lei de Segurança Pública $n^{\circ} 20$.

${ }^{52}$ Ver, por todos, PACE, Problematica delle Libera Costituzionali; cit., 320.

${ }^{53}$ Assim, Giocoli NACCI, Libertà di Riunione, in Trattato di dir. amm., diretto da G. Santaniello, XII, Padova 1990, $167 \mathrm{~s}$.

${ }^{54}$ V. BRUNELLI, Un Caso di Tutela Carente: li divieto illegittimo di riunione per motivi di sicurezza. La a!iversa situazione nell'ordinamento spagnolo, in le garanzie giurisdizionali del diritti fondamentali, Padova 1988, 83.
} 
Atualmente, em comparação apenas com os limites dos motivos de segurança ou da incolumidade pública, parece duvidosa a conformidade à Constituição da previsão, contidos nos artigos 18 e ss. da Lei de Segurança Pública ( $n^{\circ} 773$, de 18 de junho de 1931), que adveio a possibilidade de proibir uma reunião em local público por razões de ordem pública ou de moralidade ou mesmo por falta de aviso prévio (art. 18), a ordem para impedir as manifestações ou gritos sediciosos ou lesivos para o prestígio das autoridades ou que ponham em risco a ordem pública ou a segurança dos cidadãos, ou quando crimes cometidos na reunião ou no tumulto (art. 20), bem como quando há uma exposição de bandeiras ou emblemas que são símbolos de subversão social, de revolta ou de insultos ao Estado, ao Governo ou à autoridade, ou de distintivos de associações facciosas (artigo 21). Ainda assim, a disciplina da Lei de Segurança Pública para o tema das reuniões, expressava a intenção de combater todas as formas de oposição organizada, e qualquer expressão de dissidência, ainda hoje está em vigor.

De fato, o legislador não permaneceu inerte, e interveio para restringir ainda mais as regras, proibindo a participação, sem motivo justificado, às reuniões em locais públicos ou abertos ao público fazendo uso de capacetes de proteção ou outros meios que tornem difícil o reconhecimento de sua identidade (ver art. 5, a Lei $n^{\circ}$ 152/1975, substituída pelo art. 2, Lei $n^{\circ} 533 / 1977$ ). Proibição que poderia ser considerada inconstitucional como incidente da modalidade de agregação, que deveria considerar exclusivamente o indicado pela Constituição ${ }^{55}$. Por outro lado, a disciplina de segurança pública não resulta, se não em parte, afetada por declarações de inconstitucionalidade.

A Corte Constitucional, além de ter declarado a inconstitucionalidade do disposto no art. 18 de Lei de Segurança, na parte em que impõe o aviso prévio necessário também para reuniões em lugares aberto ao público (Acórdão $n^{\circ}$ 27/1958), no entanto, mudou significativamente a sua própria orientação inicial (expressa na Sentença $n^{\circ}$ 54/1961), que considerava o aviso prévio como uma condição para a legitimidade da reunião, afirmando na Sentença $n^{\circ}$ 11/1979 que, tais como reuniões, não precedidas por aviso, pode muito bem atentar para a segurança e à incolumidade pública, assim reuniões, sem prévio aviso, poderiam ocorrer sem que houvesse qualquer risco à segurança e à incolumidade pública ${ }^{56}$.

Não tem sido considerado inconstitucional o artigo 654 do Código Penal, que contém a sanção penal de que trata o artigo 20 da Lei de Segurança Pública, nem o artigo 655 do Código Penal, que pune quem participa de uma reunião sediciosa, tendo em vista que as manifestações e os gritos sediciosos

\footnotetext{
${ }^{55}$ Ver ALLEGRETTI, sobre o ordenamento público, no Riv. Trims, 1976, 497

56 Sobre esta decisão, ver Ridola, Nuovi Orientamenti della Giurisprudenza della Corte Costituzionale del caso sulla Libertà di Riunione, em Jur., 1979, 490 ss.
} 
implicam sempre em incitação para a subversão de instituições públicas e perigo para a ordem pública ${ }^{57}$.

Merece, em nossa opinião, uma censura de inconstitucionalidade também a previsão da dissolução da reunião em caso de exposição das bandeiras ou emblemas com símbolos de subversão social ou rebelião ou desrespeito ao Estado, o Governo ou às autoridades ${ }^{58}$, especialmente, à luz da Sentença $n^{\circ}$ 189/1987, pelo qual o Tribunal Constitucional declarou a inconstitucionalidade da norma que exige punição penal aos transgressores, da preventiva autorização das autoridades públicas locais para a exibição pública de cartazes. Na presença de um quadro normativo para encontros em grande parte na época fascista, portanto, parece adequado após, identificado possíveis causas de inconstitucionalidade, operar uma leitura da disciplina vigente que traga mais possibilidades conforme o disposto no art. 17 da Constituição, seguindo essa linha mais recente da doutrina e, em particular de Pace, na problemática da liberdade constitucional (em particular 315 e ss.).

Dessa forma, a previsão da dissolução da reunião, nos casos determinados pelas leis de segurança públicas, deve ser considerada válida apenas se não houver possibilidade de assegurar a remoção pacífica (a prisão nos casos previstos na lei penal) dos participantes que, por hipótese, estejam armado ou cometeram um crime ou simplesmente perturbaram o desenrolar pacífico da reunião. Somente quando não seja de fato possível, por exemplo, pela quantidade de pessoas armadas ou pela conivência geralmente demonstrada nos confrontos pelos contraventores, só então a autoridade pública poderá proceder a dissolução ${ }^{59}$. O mesmo vale para a hipótese, embora de constitucionalidade dúbia, o uso de capacetes de proteção ou similar que tendem a tornar dificultoso o reconhecimento da pessoa, que não implica na automática dissolução da reunião onde se está se opondo ou em tentativas isoladas para esconder sua identidade.

Assim, na leitura proposta por Pace, não poderia ser considerada inconstitucional, a previsão da possibilidade da autoridade impedir a reunião em certos locais por razões de moralidade ou a saúde pública (artigo 18 , $\S 4^{\circ}$ da Lei de Segurança Pública), sempre que através do primeiro limite (moralidade), tivessem a intenção de impedir qualquer "manifestação contrária aos bons costumes" para o qual por lei é autorizada a estabelecer medidas adequadas a prevenir ou reprimir as violações (artigo 21, $\S 5^{\circ}$ da Constituição), e o segundo limite é destinado para a tutela da saúde, como direito do indivíduo e do interesse da coletividade constitucionalmente tutelada (artigo 32 da Constituição), podendo detectar razões sanitárias desaconselháveis para a

\footnotetext{
${ }^{57}$ V. Em relação ao art. 21 Constituição, Sentença $n^{\circ}$ 120/1957; em relação ao art. 17 Constituição, Sentença no 15/1973.

${ }^{58}$ Artigo 21 da Lei de Segurança Pública.

${ }^{59}$ PACE, op. cit., 316.
} 
participação física em um mesmo local ${ }^{60}$. Merece uma menção em separado, no entanto, o disposto no artigo $18, \S 4^{\circ}$, da Lei de Segurança Pública, na parte em que autoriza a autoridade de impedir, que a reunião ocorra em um lugar público, simplesmente por causa da falta de aviso prévio. De fato, é de ser considerada, que embora seja constitucionalmente legítima a proibição, em função da ausência do aviso prévio, seja possível deduzir a periculosidade da reunião para a ordem pública, sendo que tal avaliação esteja sempre baseada em comprovada motivação. Fora dessa hipótese não pode descender da omissão do aviso prévio nenhum motivo de apoio de um poder genérico de proibição preventiva ou de dissolução pelo chefe da autoridade pública.

\section{A NATUREZA JURÍDICA DO AVISO PRÉVIO}

A obrigação de dar aviso prévio em reuniões realizadas, em locais públicos, não constitui uma condição de legalidade da reunião ${ }^{61}$. À autoridade não é, portanto, mais consentido impedir que a reunião ocorra apenas pelo fato da omissão de aviso prévio, nem pode ser responsabilizado penalmente aqueles que assumem a palavra em reuniões não previamente avisadas, independentemente de percepção da ausência do aviso.

A sanção penal resultante da violação da obrigação de dar o aviso prévio só se aplica contra os chamados promotores, enquanto que não constitui ilícito a simples participação em uma reunião não previamente avisada, nem a intervenção como orador no mesmo, sendo capaz de detectar, neste último caso, também uma violação do artigo 21 , parágrafo $1^{\circ}$, da Constituição ${ }^{62}$.

Portanto, parece possível, mesmo em virtude da jurisprudência constitucional, sustentar que o aviso legal tem uma natureza dupla ${ }^{63}$. Por um lado, constitui uma obrigação imposta apenas aos promotores, desta forma proporcionam um auxílio particular ao funcionamento da vigilância da polícia ${ }^{64}$, e de outro lado, um ônus aos interesses dos próprios promotores.

Cumprindo a obrigação de cooperação com as autoridades públicas, a violação será criminalmente punível, de fato, aos promotores, que agem com interesse próprio, tendendo a ser beneficiado da reunião previamente avisada da proteção das autoridades públicas. ${ }^{65}$

O aviso prévio deverá conter indicação do dia, da hora, do local e do objeto da reunião, e genericamente aqueles que serão designados para fazer uso da palavra, bem como o nome dos promotores e assinatura ${ }^{66}$. Indicações, que por fim, podem ser úteis, não tanto ao propósito de verificar a subsistência de comprovados motivos de segurança ou a incolumidade

\footnotetext{
${ }^{60}$ PACE, op. alt. cit., 317.

${ }^{61}$ Ver, neste sentido, o Tribunal Constitucional, Sentenças 11/1979 e 90/1970.

${ }^{62}$ Ver, novamente a Sentença 11/1979.

${ }^{63}$ Como PACE, Problematica delle Libertà Costituzionali, cit., 332.

${ }^{64}$ V. art. 24, Legge $n^{\circ} 121 / 1981$.

${ }^{65}$ Assim, PACE, loc. cit.; La Libertà di Riunione nella Costituzione Italiana, cit., 94 ss.

${ }^{66}$ Art. 19 da Reg. Exec. nº 635/1940.
} 
pública que possam justificar uma proibição preventiva, mas também evitar situações materiais de insegurança pública, através da disponibilização de meios de atos de proteção que permitam a realização pacífica no desenvolvimento da reunião.

Para esse fim, entende-se a proibição preventiva com extrema razão, e devendo optar-se a mesma, quando não for possível garantir outro meio de prevenção de desordem tidas como possíveis em consideração ao objeto, ao local, ao dia ou outro elemento sobre a reunião pré-avisada, um provimento da autoridade que disponha acerca do desenvolvimento de maneira diversa do tempo e do local ${ }^{67}$. Mesmo essa medida, também, deve estar adequadamente motivada, caso contrário, pode ser entendida como arbitrária ou limitadora do direito de reunião.

O exercício do direito de se reunir em um lugar público não pode se sujeitar a uma espécie de sistema de autorização, e a mesma avaliação sobre a periculosidade da reunião deve ser relatada em uma situação concreta, e traduzir-se em um procedimento pontual, resultado, portanto, ilegítimo qualquer impedimento preventivo geral ${ }^{68}$.

O aviso prévio, por fim, não é necessário para reuniões eleitorais (artigo 18, parágrafo $7^{\circ}$, da Lei de Segurança Pública), ou para reuniões estruturalmente relacionadas, quanto ao objeto e finalidade, ao desenvolvimento da função eleitoral por parte dos cidadãos e seguidos a frente de manifestações das relações subjacentes ${ }^{69}$. O regime privilegiado é justificado hoje, pela necessidade de facilitar formas de interação entre os participantes para votar de acordo com as regras do sistema democrático (veja art. 48 e 49 de Constituição), embora, no contexto histórico das Leis de Segurança Pública era tido como instrumento para manifestações políticas "plebiscitárias" de consentimento no regime fascista ${ }^{70}$.

\section{O PROBLEMA DA TUTELA JURISIDICIONAL DA LIBERDADE DE REUNIÃO}

Os amplos espaços deixados às autoridades públicas para o exercício das competências de restringir a liberdade de reunião já tinha levado à Comissão de Estudos relacionados com a reorganização do Estado estabelecida pelo Ministério da Constituição para que constasse no seu relatório que o melhor seria proteger o direito da palavra facilitando aos cidadãos a experiência de proceder, de forma rápida e eficaz contra os abusos de autoridade e sancionar graves responsabilidades contra aqueles condenados culpados sobre a questão ${ }^{71}$.

\footnotetext{
${ }^{67}$ Ver art. 18, parágrafo 40 da Lei de Segurança Pública.

${ }^{68}$ V. R. D'ALEssio, sub art. 17, in Commentario Breve alla Costituzione, a cura di Crisafulli e Paladin, Padova 1990, 110; PRISCO, Riunione, Cit., 9.

${ }^{69}$ Borrello, Riunione, cit., 1432.

${ }^{70} \mathrm{~V}$. Prisco, Riunione, cit., 8.

${ }^{71}$ Relazione all'Assemblea Constituinte, vol. I, Problemas Costituzionali. Organizzazione dello Stato, Roma 1946, 116.
} 
No entanto, na ausência de uma intervenção legislativa ad hoc, de tutela judiciária da liberdade de reunião, exercia-se somente da maneira habitual: com os recursos jurisdicionais administrativos para obter a anulação da ação ilegal de dissolução ou proibição, em sede criminal, para determinar eventual abuso ou desvio de poder de funcionário no procedimento de dissolução ou da proibição, com a ação de ressarcimento dos danos perante os tribunais civis, para os atos de ilegalidade da polícia que violassem direitos pessoais dos indivíduos ${ }^{72}$.

Em particular, considera-se que, dada a ampla lacuna deixada pelo art. 17 da Constituição ao poder discricionário da autoridade pública, o eventual reconhecimento de tais poderes legislativos (se pensa como amplo o poder de proibição concedido à autoridade para tratar das reuniões em locais públicos) excluída a configurabilidade ideal do direito subjetivo da autoridade aos participantes e aos promotores do encontro, para que estes últimos, enquanto destinatários do ato impedido possam recorrer à justiça administrativa, que determinará as condições que justificam a proibição e decidir sobre os pedidos cautelares relativos à execução do ato impugnado ${ }^{73}$, presumivelmente junto com o recurso. A este respeito, assume particular importância na nova disciplina da tutela cautelar no juízo administrativo ${ }^{74}$, tendo em vista que a pedido do recorrente, a medida relativa pode ser disposta por uma via provisória, nos casos de extrema gravidade e urgência, que não permitem a dilação final até a data da Câmara do Conselho, com um decreto fundamentado pelo presidente do Tribunal Administrativo de Recursos ou da seção da ação em que o recurso for atribuído, mesmo na ausência de contraditório ${ }^{75}$, deve ser lembrado, mais genericamente, que, à luz da Lei ${ }^{\circ}$ 205/2000, as medidas cautelares não se esgotam mais em uma simples suspensão do ato impugnado, mas incluem ordens liminares e apreensões.

Assim, fizemos uma aproximação significativa com relação à disciplina da proteção judicial contida no Código de Processo Civil perante os tribunais ordinários, ex. art. 700 do Código de Processo Civil, e as medidas consideradas aplicáveis para procedimentos incidentais acerca de direitos subjetivos, isto é, nesse caso, sobre reuniões em local privado ou aberto ao público ${ }^{76}$, ou falta de motivação ou adotadas com base nos poderes discricionários diverso daquele conferido pela norma constitucional.

$\mathrm{O}$ artigo 700 do CPC consente, como se sabe, para àqueles fundados motivos de que se, durante o tempo necessário para fazer valer o seu direito na via ordinária, estiver ameaçado por um dano imediato e irreparável recorrer ao Tribunal para exigir o procedimento de urgência que demonstra, segundo

\footnotetext{
${ }^{72}$ V. PACE, Problematica, cit., 338.

${ }^{73}$ Artigo 21, parágrafo 90, Lei 1034/1971, alterada pela Lei no 205/2000.

${ }^{74}$ Ver Lei no 205/2000, Disposições relativas à justiça administrativa.

${ }^{75}$ Em relação com a referência específica à liberdade de reunião, ver Curry, em Diritti Fondamentali, Turim S. 2002,346.

${ }^{76}$ Sobre as quais apenas as autoridades dispõe de poderes repressivos.
} 
as circunstâncias, mais adequados para assegurar provisoriamente os efeitos da decisão sobre o mérito.

Tal remédio se apresenta, porém, como totalmente insatisfatório, não permitindo que se obtenha por horas a suspensão de um ilegal procedimento lesivo do direito de reunião ${ }^{77}$ claro, a previsão de uma decisão de forma relativamente rápida, agora reconhecida até mesmo em sede da jurisdição administrativa, por meio da expansão dos poderes do juiz, permite a superação de algumas preocupações levantadas na proposição, mas a resistência da jurisprudência sobre a aplicabilidade do artigo 700 CPC, na matéria dos direitos individuais e até mesmo na impossibilidade prática de obter por meio de tal procedimento uma medida de reintegração acerca dos sucessivos provimentos de dissolução ou de remoção de alguns participantes, induz ainda hoje a confirmação da necessidade, há muito identificada por Pace, da instituição de um procedimento jurisdicional ad hoc, rápido e eficaz ${ }^{78}$.

E a situação precária da liberdade de reunião, que aparece desprovida da adequada tutela, não pode deixar de se preocupar fortemente, até mesmo pela importância que assume o exercício do direito de reunião, se comparado a outros direitos fundamentais, em primeiro lugar para a liberdade de expressão do pensamento.

Isso não está em jogo, como tem sido autoritariamente tratado, apenas com a manutenção e fortalecimento de um direito constitucional único, mas qualquer coisa a mais: a própria possibilidade de expressar opiniões divergentes, ou de qualquer modo, não 'canonizado'. Por outro lado, a liberdade não consiste em pontos isolados e de isolamentos, cada um é capaz de viver uma vida própria. A diminuição de uma - ou a sua paralisação - é a diminuição de toda a esfera de liberdade ${ }^{79}$.

\section{NOTAS HISTÓRICAS SOBRE A LIBERDADE DE ASSOCIAÇÃO}

Os eventos históricos da liberdade de associação estão intimamente relacionados com o processo de gradual superação da hostilidade dos poderes públicos em comparação com as instituições intermediárias que acompanharam a formação do Estado moderno. A liberdade de associação era de fato considerada pela maioria como a progressiva afirmação da soberania do Estado sobre ordenamento privado ${ }^{80}$, de acordo com uma atitude incorporada na corrente do pensamento formado durante a Revolução Francesa e que inspirou as constituições e as leis do continente europeu no século XIX. A desconfiança contra as associações que manifestavam a ideologia jacobina democrática, que era considerava nas classes intermediárias, como um obstáculo para a completa realização da igualdade

\footnotetext{
${ }^{77}$ PACE, La Libertà di Riunione nella Costituzione Italiana, cit., 198 ss.

${ }^{78}$ PACE, La Libertà di Riunione, in Pubblica Sicurezza, cit., 271.

${ }^{79}$ CARLASSARE, Introduzione a Le Garanzie Giurisdizionali dei Diritti Fondamentali, cit., 3 e 4.

80 REHDLA, Democrazia Pluralistica e Berth Associative, Milano 1987,30 ss.; Associazione, Le Libertti di Associazione, in Enc. giur, 111, Roma 1988 parte. 1.
} 
entre os cidadãos e como o diafragma na formação da vontade geral, é a ideologia liberal, que de um lado se manifestava em oposição ao fenômeno da formação da base corporativa, e de outro considerava que a associação era fruto de um processo espontâneo de agregação de alguns indivíduos, como mero reflexo da liberdade individual.

Mas, se o associacionismo voluntário foi tolerado, enquanto expressão da esfera privada individual, essa atitude foi fortemente redimensionada pelo efeito da posição de grande suspeita de oposição às associações políticas, cuja função era se posicionar em oposição à concepção liberal de representação política baseada na separação entre Estado e a sociedade civil.

As associações políticas se contraporam em função dos objetivos liberais da unidade de esfera política ${ }^{81}$. Por outro lado, e não ao acaso, foi na própria forma associativa que se expressou o movimento operário para reivindicar os direitos políticos, a liberdade civil e a igualdade negada pelo regime burguês liberal. De outra parte, ainda quando a liberdade de associação foi reconhecida (na Constituição Francesa de 1848), essa mesmo proclamada como direito absoluto do cidadão, foi acompanhada de "nota marginal" para que pudesse ser considerada ilimitada, na medida em que não estavam sendo colocados um limite das igualdades dos direitos de terceiros e da segurança pública, ou de leis que tinham exatamente a tarefa de manter essa harmonia. ${ }^{82}$

Todavia, a citada nota marginal, serviu também como referência aos demais direitos de liberdade reconhecidos na Constituição Francesa de 1848, dispondo que cada parágrafo dessa última que contivesse oposição: na proposição geral, na liberdade, na nota marginal, na supressão da liberdade ${ }^{83}$, e as limitações das liberdades para o interesse da segurança pública traduzia-se em limitações dos interesses da segurança da burguesia ${ }^{84}$.

Assim, até que a expressão "liberdade" fosse respeitada e fosse apenas obstaculizada, por meios legais a verdadeira realização da mesma, e a existência constitucional da liberdade fosse ilesa, intacta, bem como a existência real foi arruinada $^{85}$, na Itália, o silêncio do Estatuto Albertine, que mencionava apenas o direito de reunião (art. 32), teve cobertura superior pela doutrina e pela jurisprudência que, forte para intervir na supressão do sistema de autorização prévia previsto originalmente nos artigos 483-486 do Código Penal da Sardenha de 1839, não tinham dúvidas quanto ao reconhecimento da liberdade de associação por parte do ordenamento. Mas o sistema que

\footnotetext{
${ }^{81}$ V. RIDOLA, Democrazza Pluralistica, cit., 101 ss.; G. BRUNELLI, Struttura e Limiti del Diritto di Associazione Politica, Milano 1991.

${ }^{82}$ V. Cap. II della Cost. Francese, § $8^{\circ}$.

${ }^{83}$ MARX, Il 18 brumaio di Luigi Bonaparte (1851), trad. it. di Togliatti (1964), Roma 1997, 69.

${ }^{84}$ Assim como para a liberdade de associação, por meio da Lei de 19 de junho 1849, que vetava os clubes que pudessem comprometer a segurança pública.

${ }^{85}$ Marx, loc. cit.
} 
vinha sendo gradualmente construído, em relação não só as associações política e religiosa, se baseava em um regime de precária tolerância, não raro interrompida por medidas repressivas dos órgãos de governo ${ }^{86}$.

O desenvolvimento do movimento sindical e o papel exercido pelo governo de mediação nos conflitos trabalhistas entre as associações de trabalhadores e associações patronais favorecida, no alvorecer do século $\mathrm{XX}$, trouxe uma diferente consideração do fenômeno associativo. Mas a transformação, em ato interno do modelo originário liberal, relativamente às coalizões de trabalhadores não se traduziu em um tema de evolução legislativa.

Em tal situação, o fascismo teve um modo significativo, traduzindo legislativamente práticas iliberais do regime anterior. Insere-se neste quadro as formas de reconhecimento ao prefeito do poder de vigilância, e de possivelmente, a dissolução das associações com base em apenas no genérico pressuposto da periculosidade ${ }^{87}$.

A vontade de conquistar e de controlar as aparições políticas e burocráticas se manifestavam, através da inclusão de associações profissionais no interior das estruturas jornalísticas. Também foi introduzida pela Lei $n^{\circ} 2029$, de 26 de novembro de 1925, um mecanismo de penetração genérico de publicidade para as associações, que autorizava apenas a publicação segura e facultava o poder de tornar operante, por razões de ordem pública e de segurança pública. Esta lei, apresentada como uma resposta essencialmente contra a maçonaria, e configurava-se na realidade como o primeiro ato do fascismo para afirmar aquilo que o partido fascista chamou de sua revolução ${ }^{88}$, como um ato através do qual o regime pretendia atingir todas as formas de oposição organizada.

O poder do prefeito de dissolução foi posteriormente alargado às associações que com envolvimento em atividades contrárias ao ordenamento político estabelecido no Estado ${ }^{89}$, e dessa forma, acompanhavam-se as previsões das autorizações prévias do ministro interno para a Constituição de associações de caráter internacional ${ }^{90}$, a situação foi concluída pela previsão no Código Penal de 1930, junto com a associação criminosa já considerada pelo Código de 1889, como a nova figura criminosa da associação subversiva ${ }^{91}$.

\section{O PLURALISMO DOS ORDENAMENTOS SOCIAIS}

A própria vontade da repressão do fenômeno associativo manifestada e, em grande parte realizada, no período fascista constitui até agora a inegável

\footnotetext{
${ }^{86}$ De Siervo, Associazione (libertà di), in Dig. disc. pubbl., I, Torino 1987, 485.

${ }^{87}$ V. Art. 218, da Lei de Segurança Pública de 1926 e DE SIERVO, Associazione, cit., 486; bem como, mais em geral, Libertà di Associazione e Poteri al Polizia Profili Storici, in La Pubblica Sicurezza, a cura di Barile, Vicenza 1967.

${ }^{88}$ Discurso de Gramsci para a Câmara dos Deputados, publicado em um panfleto intitulado Contra la Legge sulle Associazioni Segrete, Roma 1997.

${ }^{89}$ Art. 210 da Lei de Segurança Pública.

${ }^{90}$ Art. 211 da Lei de Segurança Pública.

${ }^{91}$ Art. 270.
} 
necessidade de presença interna do Estado em ordenamentos sociais ${ }^{92}$. As mesmas escolhas da assembleia constituinte foram inevitavelmente marcadas não só pela vontade de reação relativa ao regime fascista, mas também e sobretudo da necessidade de reversão da premissa de desconfiança e de hostilidade para com a livre manifestação do pluralismo social ${ }^{93}$, bem como a necessidade de não só apostar na experiência italiana, mas se ligar ao processo mais geral de pluralização do ordenamento social, mesmo dentro da ordem estatal, que começou a tomar forma própria com a crise da homogênea sociedade livre, que correspondia à crise do moderno ordenamento estatal.

O desaparecimento da homogeneidade social, de fato, atingiu profundamente as construções teóricas do Estado liberal de direito, e marca a passagem do Estado social na forma institucional do Estado constitucional de direito, determinando a sobreposição da Constituição à lei. A Constituição remove áreas importantes da lei, estabelecendo analiticamente os valores fundamentais e propondo, segundo a observação da definição helleriana, a organização da liberdade humana na realidade social. Essa emblemática passagem trata-se do sistema da Constituição de Weimar de 1919, contendo um veto, e o próprio catálogo de direitos fundamentais. A Constituição não definiu só em uma regra abstrata quando a posição do sujeito em relação aos poderes públicos, mas também considerou as reais condições da vida dele, não mais indiferente, como no passado, no seu conteúdo. Assim, a relevância do reconhecimento dos interesses sociais altamente diferenciados, sugerindo que a formação não é mais uma ordem racional baseada nas leis da natureza, como aconteceu na primeira Carta Constitucional, nas primeiras declarações de direitos do homem no constitucionalismo, mas apenas divisões dos antagonismos da sociedade, marcando o nível mais alto do reconhecimento da necessária presença interna do Estado em uma pluralidade de sistemas sociais.

Portanto, é possível afirmar que, não obstante os processos de pluralização dos demais ordenamentos sociais não representaram uma novidade absoluta da sociedade contemporânea, porque as suas raízes estavam muito além da mesma afirmação do Estado moderno, o seu reaparecimento dentro do ordenamento estatal é um fenômeno relativamente recente. E, a relevância desse reaparecimento foi entendida, como apontado por Modugno ${ }^{94}$, para induzir a ciência jurídica a superar o ponto de vista estatístico e desembarcar na pluralidade dos sistemas jurídicos, ou da sociedade de direito. Não se trata mais da pluralidade monotípica apenas do ordenamento estatal, mas da pluralidade politípica do ordenamento das mais variadas caracterizações ${ }^{95}$.

\footnotetext{
${ }^{92}$ Sobre a ênfase no elemento estruturador para a mesma definição das associações, V. Crisafulli, Associazione (diritto civile), Torino 1939, 1035 e ss.

${ }_{93}$ DE SIERVO, Associazione, cit., 487.

${ }^{94}$ Pluralità degli Ordinamenti, in Enc. dir., XXXIV Milano 1985, e, Legge - Ordinamento Giuridico Pluralità degli Ordinamenti, Milano 1985, 198.

${ }^{95}$ V. Santi Romano, L'ordinamento Giuridico (1918), II ed., 1946, Firenze 1951; CAMMARATA, II Concetto del Diritto e ía Pluralità degli Ordinamenti Giuridid (1926), ora in ID., Formalismo e Sapere Giuridico, Milano 1963, 2101.
} 
No âmbito dessa pluralidade politípica inserem-se os ordenamentos de formação espontânea que, ao contrário daqueles estabelecidos pelo ordenamento geral, são verdadeiros ordenamentos, cuja energia criativa e normativa possam resultar de tais condições ou, contudo, incidam sobre o ordenamento geral ${ }^{96}$. Basta pensar na influência dos partidos políticos, das associações sindicais, das federações e uniões industriais; agrícolas, comerciais, etc. Possibilidade de condicionamento que resulta no retorno da condição, como observado por Modugno, que considerados do ponto de vista de ordem geral, que vai do mínimo da irrelevância, através da explícita permissão (legalidade), ao máximo da garantia que pode, por sua vez, ainda mais graduá-los, segundo a minoria ou a maioria de suas especificidades, podendo resguardar a categoria em gênero (ex. associação - art. $18 \mathrm{da}$ Constituição) ou simples tipos de formações e associações (por exemplo, a família art. 29 da Constituição, os sindicatos ex. art. 39, e os partidos políticos nos termos do art. 49).

\section{O RECONHECIMENTO CONSTITUCIONAL}

$\mathrm{Na}$ escala de possíveis relações entre o ordenamento geral e os ordenamentos que são a expressão de qualquer comunidade ou grupo social organizado, a Constituição Republicana fixa a relação referida ao nível máximo, que é o da garantia. Reconhece, de fato, o direito dos cidadãos de associar-se livremente, sem autorização, para fins que não são proibidos aos indivíduos pelo direito penal (artigo 18, parágrafo $1^{\circ}$ ).

O conceito de associação, aprovado pela assembleia constituinte, parece compreender não só as associações que usamos para definir, de acordo com direito privado como "reconhecidas" (artigo 12 do CC) e "não reconhecida", ou sem personalidade jurídica (artigo 36 do CC), mas também aquelas não cumprem os requisitos estabelecidos no art. 36 e ss. do CC, como o fundo mútuo e a representação externa ${ }^{97}$.

Do artigo 18 seria possível, em outras palavras, inferir o estatuto geral do fenômeno associativo ${ }^{98}$, sobre as regras gerais se anexaram as regras especiais previstas nos artigos $8,19,20,39,43$ e 49 da Constituição ${ }^{99}$, respondendo às necessidades de escalas diferentes de questões entre o ordenamento geral e os ordenamentos expressados pelos grupos sociais que levam em conta as especificidades dos tipos de associações e as formações nos artigos ora suscitados.

\footnotetext{
${ }^{96}$ MODUGNO, Pluralitá, cit., 222.

97 Conforme PACE, o sub art 18, in Comm. Cost Branca, Bologna-Roma, 1977, p. 194 e ss. entende-se como de fato a associação de participação, as associações entre profissionais de mera relevância interna e o consórcio voluntário entre proprietários de fundos vizinhos.

${ }^{98}$ V. PACE, op. cit., 204; BARTOLE, Problemi Costituzionali della Liberta di Associazione, Milano 1970,9 ss.

${ }^{99}$ PALADIN, Diritto Costituzionale, III ed., Padova 1998, 641.
} 
Uma ênfase especial entre as formações sociais, certamente, pertence aos partidos e sindicatos. É exemplar, nesse sentido, o teor do artigo $12 \mathrm{da}$ Carta dos Direitos Fundamentais da União Européia, onde, em termos de liberdades da reunião e de associação, faz referência específica aos setores políticos e sindicais, sublinhando, por outro lado, a importância do papel dos partidos políticos para nivelamento da união contribuindo para expressar a vontade política dos cidadãos da União ${ }^{100}$. É fácil compreender a íntima conexão que liga o reconhecimento do direito de livre associação ao princípio pluralista, no sentido de compreender as tendências - enquanto limitada as formações dos grupos sociais com características voluntárias ${ }^{101}$, de multiplicar as expressões do espírito associativo contidos no artigo 18, parágrafo $1^{\circ}$. Conexão que fica evidente em virtude da previsão que impede as associações apenas dos propósitos proibidos aos indivíduos pela lei penal, para o qual a esfera de ação das associações seria virtualmente considerada como equivalente ao indivíduo.

A nossa Constituição parece admitir, portanto, todas as associações, não estabelecendo uma forma de proteção à democracia. Ao contrário, por exemplo, conforme o previsto pela Constituição alemã (art. $9^{\circ}$ ), na qual dispõe que associações, cuja finalidade, ou cujas atividades contrastem com a lei penal, ou que sejam contra o ordenamento constitucional, ou contra os princípios do entendimento entre os povos, são proibidas ${ }^{102}$.

Enquanto tal equalização não fosse assegurada constitucionalmente, estaria privada a sua capacidade expansiva ${ }^{103}$ de concretização do princípio pluralista e da autonomia das formações sociais, que se expressam principalmente no art. $2^{\circ}$ da Constituição ${ }^{104}$.

Atualmente, a própria capacidade expansiva das disposições constitucionais relativas à liberdade de associação, instigada por trás dos valores do pluralismo, permitem considerar a liberdade de associação vinculativa ao desenvolvimento da personalidade individual, pelo menos no sentido de impedir a tendência de consolidação do poder privado em organizações sociais, contendo a cristalização das posições hegemônicas ${ }^{105}$. A amplitude do termo constitucional de associação não legítima, portanto, qualquer enrijecimento das estruturas associativas, na medida em que a realização do pluralismo é realizada em conformidade com as disposições constitucionais,

\footnotetext{
${ }^{100}$ Art. 12, § $2^{\circ}$, reproduz o conteúdo do artigo 191 do TCE; v. art. 11-72 do Tratado que adota uma Constituição para a Europa, assinado em Roma 29 outubro de 2004.

${ }_{101}$ PALADIN, Diritto Costituzionale, cit., 642.

102 Sobre o problema das organizações subversivas no ordenamento italiano (v. contudo infra, item 10).

${ }^{103}$ Ridola, Democrazia Pluralistica, cit., 146; Associazione, cit., par. 2.1.

${ }^{104}$ MORTATI, La Persona, lo Stato e le Comunitâ Intermedie, Roma 1959, 73 ss.; P. RESCIGNO, Persona e Comunità, Bologna 1966; BARBERA, sub art. 2, in Comm. Cost. Branca, BolognaRoma 1975, 101 ss.; RIDOLA, Associazione, cit., pat 2.1; E. ROSSi, Le Formazioni Sociali nella Costituzione Italiana, Padova 1989, 142.

${ }^{105}$ RIDOLA, Dirittti di Liberta e Costituzionalismo, Torino 1997, 86.
} 
não sendo deixado à mercê da mera espontaneidade apenas nas relações de poder entre grupos sociais ${ }^{106}$. O que equivale, no entanto, para garantia das pessoas à liberdade autêntica entendida como vontade racional, com plena consciência em torno da autonomia (selbständigkeit) pela própria existência em torno da necessidade da realização de sua própria essência ${ }^{107}$.

Não por acaso, a Constituição enfatiza a liberdade de se associar a qualquer cidadão, mesmo antes da associação como tal liberdade que se traduz no direito de constituir associações de qualquer gênero, para integrar associações já existentes em respeito aos seus fins institucionais, das normas estatutárias e no direito de denunciá-la. Devidamente tutelados são os direitos de quem não pretende se associar (assim chamada liberdade negativa de associação) sendo propositadamente excluídas as associações coercivas (ver art. 20, parágrafo, $2^{\circ}$ da Declaração Universal dos Direitos Humanos: ninguém pode ser obrigado a pertencer a uma associação). As restrições desse direito de liberdade, que neste caso surge de um poder próprio do Estado de forçar uma colocação associativa aos pertencentes a uma determinada categoria, não pode depender de qualquer interesse público (como parecia inicialmente considerada pelo Tribunal Constitucional: v. Sentença $n^{\circ}$ 69/1962), cujos meios de subsistência seria deixada à apreciação do legislador ordinário, mas deve ser baseada em outros princípios constitucionais, e ser derivado do sistema da Constituição (Sentença nº 40/1982).

Além disso, a solução elaborada pela jurisprudência constitucional, poderia ter lugar nas formas de associação obrigatória apenas na esfera do objetivo disposto inequivocamente conforme o disposto na Constituição, não se aplica a evitar dúvidas, porque, como observado por Ridola ${ }^{108}$, ocorre perguntar se, nos campos que não são inteiramente subtraídos as disponibilidades do privado, para garantir o reconhecimento da natureza pública com alguma finalidade seja suficiente, se justificar uma imposição de vínculo aparentemente necessário pertencentes à associação. A resposta pode ser afirmativa apenas se você aderir a perspectiva do tipo corporativista, que considera o artigo 18 como uma norma meramente residual, inversamente, a partir de um estilo pluralista, terá que inclinar-se para a negação, reconhecendo o artigo 18 Constituição como a norma fundamental da disciplina que rege os fenômenos associativos.

Mas essa última opção, implica na escolha de um critério orientador que transcende a hipótese de limitação da liberdade nas restrições expressas em um nexo associativo, pertencentes a uma classe específica e investe na solução de quaisquer questões decorrentes com relação aos limites da liberdade de associação. Se esta opção de fundo não estiver devidamente delimitada, é provável que traduza a expressão da sociabilidade da pessoa,

\footnotetext{
${ }^{106}$ RIDOLA, loc, cit.

107 HEGEL, Fenomenologia dello Spirito (1807), trad. it. a cura di Cicero, Milano 1995, 1059.

${ }^{108}$ Ancora in tema di libertà negativa di associazione, in Giur. cost., 1987, 333 ss.
} 
que se expressa em uma pluralidade de comportamentos, no direito a fazer qualquer atividade. Ora, se é verdade que a sociabilidade da pessoa é um bem constitucionalmente protegido de um complexo de disposições constitucionais incluídas no art. 18, não basta para determinar uma prevalência automática em relação a quaisquer outros valores conflitantes, do que tem sido descrito recentemente pelo Tribunal Constitucional como princípio da liberdade social.

$\mathrm{Na}$ verdade, a própria ideia de liberdade social invoca a ideia kelseniana de liberdade jurídica, como liberdade limitada, ou seja, a articulação constitutiva dessa em um determinado ordenamento de valores supremos

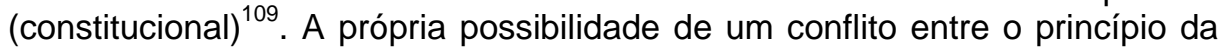
liberdade social que melhor seria definido como um valor, e outros valores constitucionais leva a atribuir uma importância decisiva no exercício da liberdade supracitada. Assim, se a atividade é realizada com continuidade e com um objetivo de lucro e, portanto, qualifica-se como uma atividade econômica, pode-se muito bem afirmar as responsabilidades aos limites estabelecidos pelo art. 41 da Constituição e as leis que regem a atuação. Nesse sentido, se expressou recentemente o Tribunal Constitucional em relação a algumas disposições da Lei da Região da Liguria $n^{\circ}$ 15/1986 contendo a disciplina das agências de viagens e de turismo, entendendo coerente com o regime constitucional da iniciativa econômica privada da previsão de uma autorização e de imposição de restrições razoáveis vinculadas a tutela do interesse público, onde essa atividade é realizada com a continuidade e fins lucrativos (Sentença $n^{\circ}$ 50/1998). Na verdade, no caso em espécie, não poderíamos até mesmo falar de uma solução resultante de um equilíbrio entre valores constitucionais, onde se pretende que a supracitada atividade, enquanto econômica, determina, também que se faça em parceria, a aplicação exclusiva do art. 41.

Por outro lado, quando for considerado aplicável também a disposição do art. 18 em relação com a atividade econômica exercida em forma associativa, e não pode prescindir da exigência coordenada entre o artigo 18 e artigo 41 da Constituição. A melhor e mais genérica coordenação entre o artigo 18, e as outras disposições constitucionais, que restringem as atividades da esfera privada. Se não quisermos escapar dessa exigência, afirmamos como antes relatado, nos termos do artigo 18, que é possível deduzir a regra geral do fenômeno associativo, para tanto, deve ser complementada com os outros

\footnotetext{
109 KELSEN, La democrazia (1929), trad. it., Bologna 1966, 150 ss. Conforme revelado por Baldassarre, no Estado Constitucional da moderna democracia pluralística, nas quais a liberdade tem um significado normativo, no sentido que é um valor primordial entre os valores (supremos), determinantes para tornar o que Max Scheler chama de a legalidade das ações, ou seja a compatibilidade (validade) da escolha individual que se traduz na ação com o sistema de valores que aquele se refere (BALDASSARRE, Libertà, II Problemi Generali, in Enc. giur., XIX, Roma 1990, a liberdade social é portanto liberdade situada (ou liberdade do homem situado, segundo a definição de Burdeau), que é a liberdade interna das relações sociais (jurídicas), sobre esse ponto v., também, BALDASSARRE, op. cit., par. $3^{\circ}$.
} 
artigos, para que o mesmo artigo, em alguns casos, não seja o único que discipline a matéria, embora sendo suscetível de se expandir, quando não encontramos limites fundados nas disposições constitucionais ${ }^{110}$.

No contexto ora traçado, a associação pode ser definida como compreensiva de todas as formas de agregação, através do qual mais indivíduos, como resultado do compromisso espontâneo e recíproco, empregam para cooperar para a realização de um propósito comum, se organizando para tal fim $^{111}$. O mencionado empenho segue, pela finalidade da associação seja licita, uma obrigação para os sócios ficarem juntos, por um período determinado ou indeterminado $^{112}$. Por outro lado, se a finalidade for penalmente ilícita, o vínculo, mesmo que juridicamente relevante para fins criminosos, não terá efeito juridicamente vinculativo ${ }^{113}$, próprio do contra-senso do vínculo ideal das organizações plurisubjetivas ${ }^{114}$, constituem o caráter diferencial das associações relacionadas as reuniões, caracterizada pela co-presença de uma pluralidade de sujeitos no mesmo lugarr ${ }^{115}$, a diferença natural, material e espiritual, como resultado de dois fenômenos que os participantes levam para as associações, embora ligados por um vínculo ideal, restrito aos indivíduos, enquanto nessas reuniões se tornaria pela pluralidade física, se não até mesmo em massa ${ }^{116}$.

Ocorre, todavia, revelar que citado vínculo ideal não se refere sempre e necessariamente a todos os membros. É de fato possível que o indivíduo membro se afilie numa associação, mas não concorde com todos os fins ou não participe de todas as atividades sociais, mas sendo incitado por um mero interesse pessoal, apenas como exemplo, a aplicação de condições mais favoráveis por parte de uma instituição de crédito conveniada com uma determinada associação.

A liberdade de se associar refletida na liberdade de não se associar, de não aderir a qualquer associação, próprio do elemento da adesão voluntária faz referência para operar uma distinção entre as associações e as formações sociais. No âmbito da formação social a que pertencem, de fato, agregados (família, confissões religiosas, partidos políticos, sindicatos, minorias linguísticas) caracteriza-se pela participação de elementos voluntários e necessários ${ }^{11}$, nas formações associativas não necessariamente está presente o profundo substrato de afinidade espiritual e psicológica que geralmente caracteriza as formações sociais.

\footnotetext{
${ }^{110}$ BARILE, Associazione (diritto di), in Enc. dir., III, Milano 1958, 840.

${ }^{111}$ PACE, Problematica, cit., 339.

112 Salvo, neste último caso, a possibilidade de desistência de acordo com as previsões do art. 24, parágrafo $2^{\circ}, \mathrm{CC}$.

${ }_{113}$ PACE, Problematica, cit., 340.

${ }^{114}$ Esposito, Lo Stato Fascista e le Associazioni, I, Padova 1934, 12 ss.

115 PACE, Problematica, cit., 340.

${ }^{116}$ PACE, Sul Limite della Polizia dello Spettacolo e sulla diversa Garanzia Costituzionale dei Fini delle Riunioni e delle Associazioni, in Giur. cost., 1967, 1682.

117 MORTATI, Istituzioni di Diritto Pubblico, II, Padova 1976, 108 ss.; E. Rossi, Le Formazioni Sociali, cit., 111 ss.
} 
De acordo com uma outra vertente, a referência do artigo $2^{\circ}$ das formações sociais, onde se desenvolve a personalidade do indivíduo proporcionaria uma ligação com o regime geral das associações do art. 18, uma vez que os fenômenos coletivos são considerados como uma projeção da esfera individual e sendo a posição do indivíduo tutelado dentro desses ${ }^{118}$. Tutela que, assim, opera não apenas nos confrontos da comunidade espontânea, mas também aqueles com autoritaridade constituída pelo poder público (por exemplo, a comunidade militar ou corporações públicas de participação obrigatória), daqueles que são formados ao abrigo do artigo $2^{\circ}$ da Constituição.

$\mathrm{E}$, em verdade, o Tribunal Constitucional parece estender as garantias do art. 18 em relação às formações sociais que não são tradicionalmente incluídas entre as associações. Isto pode ser entendido como referência à liberdade de adesão subjacente à declaração de inconstitucionalidade do sistema de inscrição obrigatória para a comunidade judaica, que também são enquadrados por uma grande parte da doutrina entre os credos religiosos mas, salvo nos casos indicados e pela inconstitucionalidade da previsão de obrigatoriedade da participação dos caçadores na federação da caça ${ }^{119}$, o Tribunal tem repetidamente não considerado inconstitucional a previsão de adesão obrigatória à comunidade, havendo uma estrutura de associação. Pense nas associações profissionais, as federações desportivas, os entes públicos com base associativa ou consórcios.

No entanto, as próprias soluções muito diversas oferecidas pela jurisprudência constitucional, sugerem que não é exatamente o "direito de não se associar" ou de se retirar das associações para aplicar no que diz respeito às formações sociais quanto o valor personalista que permeia nossa Constituição e considera sua referência textual no artigo $2^{\circ}$ da Constituição ${ }^{120}$. A mesma liberdade de adesão pode ser referida também (mas não apenas) no art. 18 e se destaca, mais em geral, em princípio que é movimentado por trás de valores pessoais, tendencialmente aplicados às formações sociais. E, a maior ou menor capacidade de adesão do princípio da liberdade deve ser medida, em relação à natureza das situações em exame e a particular disciplina constitucional que refere aos indivíduos formados socialmente. Assim, não pode ser adequadamente chamado, pelo menos, na plenitude do alcance, em comparação com família como formação necessária de adesão obrigatória (sociedade natural fundada no matrimônio, art. 29 da Constituição). Pode (ou deve) ser, pelo contrário, invocado com respeito à comunidade religiosa, em reconhecimento a todos os direitos de professar livremente sua fé religiosa, sob qualquer forma implica também o direito de não professá-lo (assim chamada liberdade negativa de religião).

\footnotetext{
${ }^{118}$ PACE, sub art. 18, cit., 192.

${ }_{119}$ Ver Sentença ${ }^{\text {os }}$ 69/1962 e 71/1963.

${ }^{120}$ A República reconhece e garante os direitos invioláveis do homem, tanto como indivíduo e em grupos sociais, onde se desenvolve personalidade humana...
} 


\section{OS LIMITES DOS FINS VETADOS PELA LEI CRIMINAL COMO GARANTIA DA LIBERDADE DE ASSOCIAÇÃO}

O artigo 18 da Constituição também faz referência ao propósito para o qual é possível se associar, individualizando a negação entre o que não é proibido por lei penal. E, trata-se de um limite que traduz-se em uma garantia, ou seja, na afirmação do que é penalmente lícito para o indivíduo, e que não pode ser vetado para uma associação. Já foi dito, todavia, que a liberdade se refere ao fim associativo e não determina a subtração da atividade desenvolvida, em forma associativa aos limites baseados em outras disposições constitucionais. Problema, nesse último, que se aplica principalmente nas formas associativas em decorrência das exigências e das necessidades de produção econômica que não se beneficiam das garantias estabelecidas no art. 18, escapando quando, em virtude das atividades assumem, o sistema delineado no artigo 41 da Constituição $0^{121}$.

Então, existe uma outra consequência da previsão para as associação que são negadas apenas pelos fins proibidos da lei penal, ou seja, uma eventual declaração de inconstitucionalidade de infrações penais relacionadas com o indivíduo deve implicar na caducidade do correspondente caso de associação criminosa ${ }^{122}$.

Assim, a declaração de inconstitucionalidade do art. 272, parágrafo $2^{\circ}$, do Código Penal que punia a propaganda antinacionalista (Tribunal Constitucional $n^{\circ} 87 / 1966$ ) não pode aludir no artigo 271 do $C P$, que pune 0 que promover, fundar, organizar, dirigir ou participar nas associações que propaguem o desenvolvimento ou que desenvolvam uma atividade direta a destruir ou a denegrir o sentimento nacional ${ }^{123}$, pelo simples motivo que se não é um ilícito penal que o sujeito pratica de propaganda destinado a este fim - onde não transmite violência ou outra atividade que viole outros bens constitucionalmente garantidos com o fim de integrar outras figuras criminosas não constitui ilícito, nem sequer a atividade associativa voltada para realizar aquilo que é consentido ao indivíduo, como é estabelecido pelo art. $18 \mathrm{da}$ Constituição, que a reconhece - nos limites estabelecidos no segundo parágrafo da liberdade de associação - pelos os fins que não são proibidos aos indivíduos pela lei penal ${ }^{124}$, uma abertura nesse sentido talvez pudesse compreender, embora com certa força, também no mais amplo reconhecimento, operado pelo Tribunal Constitucional (v. Sentença $\left.n^{0} 189 / 1987\right)$, a possibilidade de expressão das diferentes entidades políticas e sociais, não só sobre as minorias étnicas, mas também os grupos intermediários, os entes públicos e

\footnotetext{
${ }^{121}$ V. MIELE, Problemi Costituzionali ed Amministrativi della Pianificazione Economica, in Riv. trim, dir. pubbi., 1954, 793 e V. SICA, Le Associazioni nella Costituzione Italiana, Napoli 1957, 39 ss.).

${ }_{122}$ Ridola, sub art. 18; in Commentario breve alla Costituzione, a cura di Crisafulli e Paladin, Padova 1990, 114.

${ }^{123}$ VASSALI, in, Propaganda Sovversiva e Sentimento Nazionale, in Giur. cost., 1966, 1103.

124 Sobre o assunto Tribunal Constitucional Sentença $n^{\circ} 243 / 2001$, declara a ilegitimidade constitucional do art. $271 \mathrm{CP}$.
} 
os privados em geral. De fato, o princípio da identidade ou da individualidade político social que se põe fundamentado na Sentença 189/87, declarava a ilegitimidade constitucional da norma que exigia, que a transgressão fosse punível com sanção penal, e a preventiva autorização das autoridades públicas locais para a exibição pública de bandeiras com símbolos. A partir desse princípio, deriva no caso em espécie, a possibilidade de reconhecer e de expressar sua identidade política e social, através de um símbolo, uma bandeira correspondente a um Estado estrangeiro, precisamente porque, em geral, o Estado democrático não tem que impor seus próprios valores de conteúdo ideológico, que investem todos os cidadãos e totalmente a cada um dos cidadãos.

Atualmente, como exatamente foi detectado ${ }^{125}$, elevam-se os valores da pessoa aos princípios supremos do ordenamento condicionado, bem para além das garantias da reserva legal para as limitações dos direitos individuais e coletivos, e o modo e a intensidade da explicação da atividade legislativa. $\mathrm{E}$, condiciona, em particular, a oportunidade para os legisladores de recorrer às sanções penais, forçando dentro dos espaços determinados a impossibilidade ou a insuficiência dos outros ramos do ordenamento geral do Estado. Condicionamento que resulta, portanto, ligado ao princípio do direito penal como extrema ratio, reconhecido na jurisprudência constitucional (v. Sentença 364/1988), que aprofunda a sua raiz no artigo $8^{\circ}$ da Declaração dos Direitos do Homem e do Cidadão (26 de agosto, 1789), para que a lei deva apenas estabelecer penas estritamente e evidentemente necessárias.

A conexão própria que é possível individualizar entre o princípio da identidade ou da individualidade político social e o princípio do direito penal como extrema ratio, induz às reflexões anteriores acerca da extensão da área de irrelevância penal, referente ao uso das organizações plurisubjetivas que se usa para definir como associações subversivas.

O crime de associação subversiva estabelecido (art. 270 Código Penal) é configurado como um delito contra a personalidade do Estado introduzido pelo Código Penal de 1930, com a clara intenção de acertar alguns pontos em comum de associações, por causa de suas ideologias revolucionárias. A matriz histórica dessa previsão emerge claramente da relação do projeto do código, no qual se manifestava a intenção do regime fascista de coibir aquelas associações que os limitavam da atividade de afirmação teórica dos objetivos políticos que constituíam o programa. Surpreende, portanto, que fora do contexto histórico político, esse instrumento de repressão da forma de oposição organizada ( $v$. infra, item 7), permaneça no nosso ordenamento republicano introduziu de fato, os limites adicionados da liberdade de associação no ordenamento público (v. também, o art. 272 do Código Penal), resultando por outro lado incompatível, como demonstraremos a seguir, em relação às previsões do art. 18 da Constituição (bem como do art. 21).

\footnotetext{
${ }^{125}$ MODUGNO, Nuovi nella Giurisprudenza Costituzionale, Turim 1.995, 34.
} 
A razão da presente previsão é a mesma que justificava o reconhecimento do poder do prefeito de dissolver as associações contrárias ao ordenamento político constituído no Estado (artigo 210 da Lei de Segurança Pública $\left.n^{\circ} 1931\right)$, que, no entanto, restou declarada inconstitucional com o julgamento $n^{\circ} 114 / 1967$, sendo consentida a atividade de associação que se propõem também a mudança dos sistemas políticos existentes, porque esse propósito era perseguido como método democrático, mediante a liberação do debate sem recorrer, direto ou indiretamente, à violência.

À luz dessa última decisão e, mais ainda, pela afirmação incisiva do princípio do direito penal como extrema ratio e do princípio da identidade política social, não parece mais adequado à interpretação proposta na doutrina para sustentar a constitucionalidade do artigo 270 do CP, que se baseia essencialmente na necessidade de fidelidade ex. art. 54 da Constituição e combinado com o art. 272, parágrafo $1^{\circ}, \mathrm{CP}$ que veda aos indivíduos de buscarem, através da propaganda e da apologia, algo que identifique os fins elencados no artigo $270^{126}$.

A objeção mais forte à tese de inconstitucionalidade do fato em espécie, considera as associações subversivas se identificadas no apelo pela violência, impedindo-se, assim, de restringir sua aplicação apenas às associações diretas, com interesse em transformar violentamente as estruturas políticas existentes $^{127}$. Esse último argumento, todavia, aparentemente recessivo à luz da introdução do art. 270 (art. 3․ Decreto-Lei no 625/1979, e Lei no 15/1980, recentemente complementada pela Lei $n^{\circ} 438 / 2001$ com o objeto da figura criminosa da associação, que se propagou a realização dos atos de violência com o propósito de subverter o ordenamento democrático. Ora, ou se restringe, aderindo à interpretação acima exposta, neste novo caso específico é essencialmente repetitivo art. 270, que contempla uma hipótese em que o elemento da violência não se concretiza em um plano criminoso, mas num programa genérico e geralmente com eventual fim de violência, vinculado por um fim ideológico, político e revolucionário ${ }^{128}$. Ao aderir a esta interpretação proposta, que aparece a mais convincente não se pode não inclinar-se para a inconstitucionalidade do art. $270 \mathrm{CP}$, caso não se considere o argumento como suficiente, que pode ser de fato decisivo, e que reprime ou melhor reforça a sua força condicionante própria em virtude do disposto no art. 270, com base no peso da origem histórica da figura criminosa da associação subversiva, ou seja, a intenção é de atingir as associações por causa de sua ideologia política da revolução ${ }^{129}$.

${ }^{126}$ BARILE, Associazone, cit. 847; MAZZIOTI DI CELSO, Lezioni de Diritto Costituzionale, II, Milão, 1985, 280, e, mais recentemente, DE SIERVO, Associazone, cit., 492.

${ }^{127}$ NUVOLONE, Le Leggi Penali e La Costituzione, Milão 1953, 52.

${ }^{128}$ RIDOLA, Associazione cit., 12.

${ }^{129}$ VASSALLI, Propaganda Sovversiva, já referido, 1100 ss. 
Por outro lado, o dispositivo constitucional se refere apenas aos impedimentos dos indivíduos da lei penal que importa excluir a possibilidade de considerar o ordenamento público como o limite dessa liberdade, mesmo que, na verdade, pareça persistir em nosso sistema como resultado da disposição contida no art. $270 \mathrm{CP}$, o disposto nesse conceito pode abrir portas de acesso à inaceitabilidade (inconstitucionalidade) intervenção da autoridade do poder executivo, em violação do princípio do direito da taxatividade penal ${ }^{130}$.

Esta exigência parece responder adequadamente à Constituição Dinamarquesa de 1953 , que oportunamente estabelece no art. $78, \S 3^{\circ}$, que nenhuma associação pode ser dissolvida por ordem do Governo. E mesmo prevista, no mesmo artigo, há a possibilidade de uma proibição temporária da associação, mas necessita proceder de pronto contra essa para obter a dissolução da realização pela autoridade judiciária.

Além disso, apesar da importância da previsão acima, a referência do direito de se associar para o alcance dos fins permitidos em lei, disposto no art, 78, § 1 da Constituição Dinamarquesa, parece constituir uma garantia menos ampla, em relação à expressa em nossa fórmula dos fins, que não são proibidos de indivíduos pelo direito penal.

A conclusão, não muito diferente, parece ter sido alcançada em relação à Constituição Espanhola de 1978, que prevendo a reserva jurisdição pela dissolução ou da suspensão da atividade das associações, considerando ilegais as associações que perseguem fins ou utilizam meios tais de configurar crimes e prescreve um regime geral de inscrição de um registro apenas com intuito de publicidade (art. 22). O legislador parece ter acolhido nesse contexto, essa tendência no momento em que há subordinação do exercício do poder governamental de dissolver por entendimento de sentença a reconstituição da organização do partido fascista ${ }^{131}$ ou da Constituição de uma associação secreta (artigo $3^{\circ}$, Lei de 25 de janeiro de 1982, $n^{\circ} 17$ ). Nesses padrões não parece ser capaz de inserir a dissolução instituída pela Lei 17/1982 (artigo $5^{\circ}$ ) para a chamada Lei P2, enquanto não baseada sobre um prévio entendimento jurisdicional, mas sobre as conclusões de uma comissão de inquérito administrativo ${ }^{132}$. $\mathrm{E}$, entre esses limites penalísticos e os limites da intervenção do poder executivo em matéria de liberdade de associação é também implicitamente reconhecido pelo Tribunal Constitucional que, na Sentença $n^{\circ}$ 193/1983, declarou a ilegitimidade dos artigos 273 e $274 \mathrm{CP}$ e, também, do art. 211 da Lei de Segurança Pública de 1931, sobre a constitucionalidade de associação internacional, sem autorização do governo.

\footnotetext{
${ }^{130}$ PACE, já referido, 231 ss.

${ }^{131}$ Artigo $3^{\circ}$, lei de 20 de junho de 1952, n 645, que autoriza o governo também a tomar a medida do decreto de dissolução, quando justificada nos fins do art. 77 da Constituição.

132 Sobre esses problemas v. Ridola, Associazione, 8, e também, par. 13.
} 


\section{A REFERÊNCIA APENAS AOS CIDADÃOS}

A referência apenas aos cidadãos de se associar livremente pode levar a excluir todos os estrangeiros (e apátridas) da garantia do art. 18 da Constituição $0^{133}$. A doutrina tem entendido, no entanto, com o tempo, a consideração das garantias dispostas para que possam beneficiar também aos estrangeiros, e impeça não mais limitações, no sentido de sua participação em associações formadas por cidadãos excluídos de qualquer afiliações políticas ${ }^{134}$. Não parece mais necessário, declarar a extensão para os estrangeiros (e apátridas) do direito de participar em associações composta também pelos cidadãos, recorrendo a argumentos como aqueles para quais impede aos estrangeiros de se reunir ou de se associar com cidadãos significaria também impedir que os cidadãos se reunam e se associem livremente ${ }^{135}$. Pelo contrário, tendo em vista as integrações feitas pelas leis ordinárias, embora, não mencionadas no texto constitucional, ao menos no que diz respeito ao direito de participar de associações, uma interpretação extensiva, melhor, e mais simplesmente opera, segundo os critérios da interpretação constitucional, que diferencia qualitativamente e quantativamente da interpretação jurídica comum, enquanto necessariamente, o duplex interpretatio: de um lado os enunciados constitucionais, mas por outro lado, os enunciados dos fatos constitutivos de outras fontes ${ }^{136}$. O trabalho do intérprete é, então, direcionado para determinar e propor, tendo em vista a normatividade dos fatos, que por sua vez volta a qualificar os enunciados constitucionais, até o ponto que se torne possível e compatível (com o entendimento ativo político-constitucional) à integração dos enunciados da Constituição ${ }^{137}$.

O problema apresenta-se com referência às associações compostas exclusivamente de estrangeiros que, não obstante, com o tempo foi identificada pela doutrina ${ }^{138}$, e não poderia ser considerada proibida, como tal, mas, os limites, não cobertos pela garantia constitucional. E, não resta dúvida, contudo, que o legislador ordinário possa estender o direito de associação também aos estrangeiros ${ }^{139}$, a condição é regulada pela lei em conformidade da norma e dos tratados internacionais ${ }^{140}$, portanto, assume relevância também os fins da interpretação constitucional, o fato que o Tratado de Maastricht de 1992, instituiu a cidadania das uniões, pelo qual é cidadão da União quem

\footnotetext{
${ }^{133}$ E como já foi dito, no entanto, a referência apenas aos cidadãos contida no artigo $3^{\circ}$ da Constituição não impede uma extensão das suas garantias relativas também aos estrangeiros: Corte Constitucional nº 62/1994, 219/1995, 509/2000).

${ }^{134}$ Como pensou MORTATI, Direito Público, II, já referido, 1160.

${ }^{135}$ V. G.U. RESCIGNO, Corso de Diritto Pubblico, IV, Ed. Riveduta, Bologna 1996, 665.

${ }^{136}$ V. MODUGNO, Introduzione a Par condictio e Costituzione Milão 1997, XVII.

137 Assim, mais uma vez, Modugno, op. cit.

138 BARILE Associazione, já referido, 844.

139 PACE, Problematica, já referido, 361.

${ }^{140}$ Artigo 10 , parágrafo $2^{\circ}$ da Constituição.
} 
tenha a cidadania de um Estado-membro ${ }^{141}$ e reconheceu aos cidadãos comunitários o exercício de direitos fundamentais políticos no Estado em que residem. À luz dessas inovações, se é considerado como realizado um movimento de cidadania pluridimensional, de acordo com a orientação disposta no Tratado de Amsterdam, de 02 de outubro de 1997, no qual declarou que cidadania da União complementa a cidadania nacional, e não a substitui.

Em essência, segundo essa orientação, cada indivíduo deve ter reconhecido a diversidade da dimensão da cidadania, de acordo com a esfera dos direitos de tempos em tempos exercidos (direitos das pessoas, direitos políticos de dimensão local, nacional ou supranacional, direitos sociais, etc. $)^{142}$. Sob esse ponto está em relevo, além disso, os Decretos-legislativos $n^{\circ} 12$, de abril de 1996, e no 197, que têm atuação na Diretiva 94/80/CE, concernente à modalidade de exercício do direito de voto e de elegibilidade nas eleições municipais para os cidadãos da União Européia que residam num Estadomembro, de que não tenham cidadania.

Assume um significado ainda maior, a matéria em tela, que a Lei 203/1994 (de parcial execução da Convenção sobre a participação dos estrangeiros na vida pública em nível local, feita em Strasburgo, em 5 de fevereiro de 1992), autorizou o Estado a reconhecer aos estrangeiros residentes a liberdade de expressão, reunião e associação nas mesmas condições que os cidadãos. Em particular, o artigo $3^{\circ}$, letra "b" da Convenção, implementada pela Lei 203/1994, prevê que o direito à liberdade de associação implica no direito para os residentes estrangeiros de criarem suas associações para a assistência mútua, de conservação e de expressão das suas identidades culturais ou de defesa de seus interesses, em respeito às questões de competência da coletividade local, bem como o direito de aderir a qualquer associação. No entanto, apesar da importância da Lei 203/1994, cumpre identificar o que ocasionou a sua aprovação no Parlamento, que tinha negado a autorização da ratificação por inteiro do Capítulo "c" da Convenção, em relação à concessão aos estrangeiros residentes do direito de voto e de elegibilidade nas eleições locais. Negação que resultou em um quadro mais amplo, onde uma tendência política contrária à extensão do status civitatis aos estrangeiros, embora o art. $9^{\circ}$ do Decreto-legislativo $n^{\circ} 286 / 1998$, estabeleça que o "cartão de permanência", previsto no parágrafo $4^{\circ}$, letra "d", para que o titular da carta de permanência possa participar da vida pública local, exercitando também o eleitorado, quando previstas no ordenamento e em harmonia com as disposições do Capítulo "c" da Convenção sobre participação de estrangeiros na vida pública local, elaborado em Strasbourg, em 05 de fevereiro de 1992.

\footnotetext{
${ }^{141}$ Art. $\mathrm{n}^{\circ} 8,1$.

${ }^{142}$ Assim, E. Grosso, La Cittadinanza: appartenenza; identità e partecipazione dallo Stato liberale allà democrazia contemporanea, in Storia d'Italia, XIV, a Lei de Justiça, editada por Violante, Turim 1998, 136 ss.
} 


\section{A LIBERDADE DE ASSOCIAÇÃO E O PROBLEMA DA JUSTIÇA ENDOASSOCIATIVA}

A liberdade de associação se conecta à liberdade na associação ${ }^{143}$, ou seja, a garantia da esfera da liberdade individual do indivíduo em relação à própria associação ${ }^{144}$, para tal fim fundamental é a previsão do artigo 24 do Código Civil, que disciplina o afastamento e a exclusão do sócio, estabelecendo limites suscetíveis de serem aplicados nos Tribunais.

No entanto, a necessidade de tutelar o indivíduo em relação à associação proveniente dos princípios constitucionais, primeiramente, o direito de ação e de defesa (artigo 24 da Constituição), e o reconhecimento e a garantia dos direitos invioláveis dos indivíduos e das formações sociais, onde se expressa a sua personalidade (artigo $2^{\circ}$ da Constituição) - pode encontrar legitimamente os limites que se fundamentam, principalmente, na previsão estatutária prescrita aos membros, em caso de conflito entre eles ou com a associação em matérias reguladas pela referida lei, não podem se valer da jurisdição do Estado. Esta previsão pode ser adequadamente compreendida se for assumido que cada comunidade pode corresponder a um sistema autônomo jurídico, ou que se tenha sistema jurídico onde se sustente os três elementos da plurisubjetividade da normalização e da organização.

Nesse contexto, se pode justificar a presença de uma "norma-vínculo de justiça" para aqueles que se tornam parte de uma coletividade organizada, globalmente intensa, se comprometendo em aceitar as normas e os provimentos adotados por essa, e para as controvérsias entre eles que surgem neste âmbito, que se referem apenas aos órgãos associativos. Tal é o caso, por exemplo, em direito desportivo, o chamado vínculo de justiça, previsto nos estatutos e nos regulamentos de cada associação, o que implica uma obrigação de organizações desportivas a aceitarem e cumprirem as normas e provimentos federais, bem como para as disputas entre eles, quando referem-se exclusivamente aos órgãos federais.

Em que pese, como parece preferível, que as federações desportivas reconhecidas pelo CONI ${ }^{145}$ não retratem essa natureza publicística, mas conservem a natureza privada, considera-se que o ingresso dos indivíduos na comunidade esportiva ocorra apenas com base em um ato de adesão espontânea e de aceitação das regras convencionadas pelos regulamentos dispostos aos organismos esportivos ${ }^{146}$. Do ponto de vista do ordenamento estatal, a previsão não se refere a sua jurisdição (chamada de vínculo de justiça) pode ser interpretada como uma cláusula contratual (de compromisso), totalmente lícita. Mas até que ponto poderia excluir a solicitação o ingresso

\footnotetext{
${ }^{143}$ BARBERA-COCOZZA - CORSO, Le Situazioni Soggetive, Le Libertà dei Singoli e delle Formazioni. II Principio di Eguaglianza, cit, 296.

${ }^{144}$ Sobre o argumento vide GUZZETTA, II Diritto Costituzionale di Associarsi, Milano 2003, 167 ss.

${ }^{145}$ Comitato Olimpico Nazionale Italiano: organização que trata do desenvolvimento e da promoção do desporto na Itália.

${ }^{146}$ SANINO, Sport, em Enc. giur, XXX, Roma 1993, 3.
} 
como associado, para resolver essas controvérsias, pode outra autoridade que não seja federal? Aderindo à tese privatística, parece possível trazer o chamado vínculo de justiça, sob o âmbito do compromisso, disciplinado pelo art. 806 e ss. do CPC, ou, mais precisamente, na arbitragem extrajudicial ou livre, em que a decisão só tem força vinculativa unicamente no consenso e na prévia aceitação das partes, que se submetem ao juízo arbitral. Com base no artigo 806 do CPC, é possível individualizar como limite genérico a arbitragem da controvérsia que estão indisponíveis no direito, ou seja, daqueles direitos que tendem a satisfazer um interesse que transcende o pretendido ao titular e, especialmente, os chamados direitos da personalidade, que constituem os atributos essenciais irreprimíveis da personalidade ${ }^{147}$.

O problema transcende no âmbito da justiça desportiva ${ }^{148}$, onde se questiona sobre a compatibilidade da justiça endoassociativa, com o monopólio estatal da jurisdição nos termos do artigo 102 da Constituição ${ }^{149}$. A Constituição estabelece, de fato, que a função jurisdicional deve ser exercida por magistrados ordinários, ou por indivíduos que assumam tal qualificação com base na norma constitucional e na norma sobre a organização judiciária do Estado. Mas tal monopólio não absorve a função de julgar, em geral, mas apenas a função do juiz nos casos, nos modos e com os efeitos estabelecidos pelo direito do Estado ${ }^{150}$, para fazer a cláusula que prescreve composição endoassociativa da lide (...) se e quando fundada em decisão, que possui o valor de pronúncia estatal, que não são executáveis ou não tem eficácia de sentença, deixa inalterada a reserva estabelecida no art. 102 da Constituição ${ }^{151}$. A justiça endoassociativa, portanto, não se coloca em relação à incompatibilidade se alguma coisa assume o papel de alternativa ou substituta com relação à função jurisdicional. Nem por essa via, pode-se dizer estabelecido um juiz especial ou uma forma de arbitragem obrigatória, assim como a arbitragem arbitrária trata do próprio fundamento em um ato negocial, na liberdade de escolha entre as partes. Se a instituição de arbitragem deriva da liberdade voluntária das partes litigantes, não pode ser considerado prejudicado nem o princípio da unicidade nem o da soberania da jurisdição ${ }^{152}$.

Não parece que a alternativa acima de função jurisdicional seja incompatível com a previsão de que ninguém pode ser afastado do juiz natural previamente estabelecido por lei (artigo 25 da Constituição) ou com o direito de apelar à justiça do Estado para a tutela dos próprios interesses juridicamente protegidos (artigo 24, parágrafo $1^{\circ}$ da Constituição). Primeiro, porque a garantia do artigo 25 , dispõe que principalmente no plano da

\footnotetext{
${ }^{147}$ Por exemplo, direito a um nome, a integridade física, à saúde, etc.

148 Sobre o tema MODUGNO, Giustizia e Sport: problemi generali, in Riv. Dir. sport, 1993, bem como, mais recentemente, RUOTOLO, Giustizia Sportiva e Costituizione, ibid, 1998.

${ }^{149}$ Bem como no art. 2907 do CC.

${ }^{150}$ CESARINI SFORZA, La Teoria degli Ordinamenti Giuridici e il Diritto Spotivo. 1933, p. 1399.

${ }^{151}$ M. BASILE, L'intervento dei Giudici nelle Associazioni, Milano 1975, 279.

${ }^{152}$ Tribunal Constitucional, Sentença nº 488/1991.
} 
competência judiciária do Estado, não consistindo no direito dos cidadãos para resolver os litígios por magistrados ordinários, as controvérsias nas obrigações assumidas pela República de impedir que sejam impostas aos que se dirigem à autoridade judiciária de um órgão diferente daquele pré-determinado por $l \mathrm{e}^{i 53}$. A compatibilidade com o direito de recorrer aos Tribunais do Estado, nos termos do art. 24 da Constituição, pode como alternativa, ser procurada não tanto na disponibilidade supostamente livre de tal direito que deriva da sua tendência a favor dos indivíduos, mas como na expressão da liberdade associativa do grupo, pode instituir uma estrutura lato sensu jurisdicional para reservar a solução das controvérsias internas.

Resta firme, que o equilíbrio entre o direito de liberdade associativa e os outros princípios constitucionais - em primeiro lugar o direito de apelar ao Estado para a tutela dos próprios juridicamente protegidos - impõe que não pode ser reservado aos organismos das associações os conflitos que disponham dos direitos fundamentais e, mais especificamente, dos direitos indisponíveis dos indivíduos.

Por outro lado, se negar a existência em absoluto dos limites para a justiça endoassociativa, implicaria no reconhecimento dos direitos invioláveis das formações sociais onde se manifesta a personalidade do indivíduo ${ }^{154}$ como abandono do sujeito ao assédio causado pelo poder privado, subtraindo-se do último à regra de harmonia com o quadro constitucional dos valores constitucionais ${ }^{155}$. Regra que não escapa nem às formações sociais especificamente constituídas pela Constituição: basta pensar no ordenamento interno da base democrática que deve ser consignado nos estatutos dos sindicatos para fins de registro (art. $39, \S 2^{\circ}$ da Constituição) ou do método democrático que deve pontuar os partidos políticos (artigo 49 da Constituição) ou para o mesmo limite dos fins não proibidos aos indivíduos pelo direito penal, art. 18 , parágrafo $1^{\circ}$ da Constituição, com referência à liberdade de associação.

\section{A PROIBIÇÃO DAS SOCIEDADES SECRETAS E PARAMILITARES}

O parágrafo $2^{\circ}$, do artigo 18 da Constituição proíbe a associação secreta e aquela que perseguem, mesmo que indiretamente, propósitos políticos mediante organizações de caráter militar.

O "segredo" foi considerado incompatível com a dimensão comunitária do direito de associação $0^{156}$, já com a dialética democrática, que exigiria a publicidade de várias formas de expressão da sociedade civil ${ }^{157}$. Considera-se também que os limites da confidencialidade estivessem ligados à ilicitude dos fins e, referi apenas para as associações que desenvolvem institucionalmente

\footnotetext{
153 BASILE, op. cit., 281.

154 Art. 2, § $2^{\circ}$ da Constituição.

155 M. SALAZAR, Giustizia Sportiva e Principi Costituzionali, 1994, I, 245.

156 SICA, op. cit., 32 ss.

${ }^{157}$ MORTATI, Istituzioni di Diritto Pubblico, cit., s. 1162.
} 
atividade contrária à lei penal, recorrer ao sigilo como condição de sua existência ${ }^{158}$, ou que a ligação operaria, em relação ao regulamento do método democrático disposto no artigo 49 , e, em seguida, que a proibição envolveria exclusivamente as associações com objetivos políticos ${ }^{159}$.

Algumas destas dúvidas interpretativas são resolvidas, através da atuação em via legislativa da proibição constitucional associações secretas, criada pela Lei 17/1982, que foi adotada por solicitação de emergência de um forte alarme social ligada às atividades desenvolvidas pela loja maçônica propaganda due. Avaliada a oportunidade de não-aplicação da disciplina da Lei de Segurança Pública de 1931 (em particular dos artigos 209 e 212), se optou pela solução de dissolução em via legislativa pela P2 e pela determinação, na mesma lei, de aplicação de determinadas diretivas de atuação das proibições dispostas no art. $18, \S 2^{\circ}$ da Constituição, ab-rogando contextualmente os artigos 209 e 212 Lei de Segurança Pública ${ }^{160}$.

O artigo 12, da Lei $n^{\circ} 17 / 1982$, estabelece o que se considera associações secretas, com as proibições contidas no artigo 18 da Constituição, nas quais, também dentro de evidente associações, ocultam a sua existência ou segredos de finalidade e de atividades sociais em conjunto ou desconhecidas, no todo ou em parte, e, também reciprocamente, os sócios, realizem atividades diretas que interfiram no exercício das funções de órgãos constitucionais, de administração pública, incluindo sistemas autônomos, de entes públicos também econômicos, bem como de serviços públicos essenciais de interesse nacional ${ }^{161}$.

A ligação entre perfil estrutural e finalístico, operado pela lei acima, parece determinar a uma restrição da aplicação da proibição de associações lato sensu políticas ou, pelo menos, capazes de constituir, também no interior das associações evidentes, os poderes ocultos e os canais subterrâneos de incidência do processo de decisão política ${ }^{162}$. A dissolução das associações secretas será definida por um decreto do Presidente do Conselho do Ministro, após prévia deliberação do Conselho, seguida de uma decisão irrevogável da decisão judicial que assegure a existência da associação secreta (artigo $3^{\circ}$ da Lei $n^{0}$ 17/1982).

As disciplinas previstas para a dissolução das associações secretas têm fortes semelhanças com o previsto, no caso de violação das Disposições Transitórias e Final da Constituição, que proíbe a reorganização, sob qualquer forma, do dissolvido partido fascista. Mas há diferenças que possuem destaque e são justificadas devido ao aumento da gravidade da hipótese

\footnotetext{
${ }^{158}$ V., por todos, LAVAGNA, Istituzioni di Diritto Pubblico, V ed., Torino 1981, 457 ss.

${ }^{159}$ PETTA, Le Associazioni Anticostituzionali nell'ordinamento Italiano, in Giur. Cost., 1973, 743 ss.

${ }^{160}$ Ver art. $6^{\circ}$ da Lei $n^{\circ} 17 / 1982$.

${ }^{161} \mathrm{Na}$ doutrina, sobre o direito de associação secreta v. BARBIERI - CONTENTO- GIOCOLI NACCI, Le Associazioni Segrete, Napoli 1984; CUOMO, Le Associazioni Segrete e l'art. 18 della Costituzione, in Scritti in onore di V. Crisafuii, II, Padova 1985, 183 ss.

${ }^{162}$ RIDOLA, Associazione, já referido. 11, It., Democrazia Pluralistica, cit., 238 ss.
} 
de reconstituição do partido fascista. Esse último, não se faz necessário atender ao trânsito em julgado da decisão, sendo suficiente, para os fins de dissolução, a condenação em primeira instância. A competência para a dissolução é atribuída ao Ministro do Interior e é prevista a possibilidade de recorrer conforme o Decreto-lei, que dispõe para o caso das associações secretas, e onde é possível, para o caso de uma emergência, apenas o recurso específico no procedimento judicial, sob a iniciativa do Procurador da República, também a pedido do governo, "com garantias decorrentes do tipo de jurisdição e controle parlamentar".

Mas, salvo a analogia acima em relação do procedimento de dissolução das associações secretas, a proibição de reconstituição do partido fascista difere substancialmente da proibição das sociedades secretas e grupos paramilitares, além de último caso da existência de uma organização militar ${ }^{163}$.

Para efeitos da proibição do art. $18, \S 2^{\circ}$ da Constituição, são consideradas associações de caráter militar - em conformidade com 0 art. $1^{\circ}$, no Decreto Legislativo $n^{\circ} 43 / 1948$ - aqueles formados por meio do monitoramento de organismos associados de corpo, repartido em núcleos, com a disciplina do ordenamento hierárquico interno análogo a militar, com eventuais adoções de diplomas ou fardas e com organização capaz também de emprego coletivo em ações de violência ou de milícia. Resulta em outra vedação também uso de uniforme ou divisão de parte de membros das associações que de qualquer modo dependa ou se relacione com partidos políticos ou indiretamente com fins políticos (artigo $2^{\circ}$, D.L n ${ }^{\circ} 43 / 1948$ ).

Parece pacífico, portanto, que a proibição constitucional sobre as associações paramilitares responda à intenção de impedir que a luta política se aproveite, ao invés da pacífica discussão, do uso de meios violentos que determinem uma atmosfera de intimidação e de temor ${ }^{164}$, por outro lado é necessário, para efeitos da proibição constitucional, que uma organização desse tipo, também persiga indiretamente fins políticos. O perfil finalista acima foi considerado decisivo pelo Tribunal Constitucional, que devido à falta de ligação a partidos políticos ou de busca, mesmo que indiretamente, de fins políticos, considerou que a proibição em questão não diz respeito à associação dos atiradores de tirolesa (gli schützen) ${ }^{165}$.

Recorda-se, também, que o artigo $1^{\circ}$, $\S 3^{\circ}$, do Vocabulário Comum para os Contratos Públicos (CPV) da Lei $n^{\circ}$ 205/1993 (que substitui o artigo $3^{\circ}$, da Lei 654/1975) proíbe qualquer organização, associação, movimento ou grupo que tenham entre suas finalidades o incitamento à violência por motivos raciais, étnicos, nacionais ou religiosos. Trata-se, obviamente, de

\footnotetext{
${ }^{163}$ Ver art. 1, Lei n ${ }^{\circ}$ 645/1952 na versão atualmente em vigor após as alterações introduzidas pela Lei $n^{\circ} 152 / 1975$.

${ }^{164}$ MORTATI, op. cit, 1163.

${ }^{165}$ V. Sentença no $26 / 1976$.
} 
comportamentos vedados também aos indivíduos, como evidenciado pelo parágrafo $1^{\circ}$, do artigo $1^{\circ} \mathrm{CPV}$, da mesma lei.

\section{A PROMOÇÃO DE ASSOCIACIONISMO}

Ao longo dos últimos anos vêm sendo realizada uma promoção assistida do associacionismo ${ }^{166}$, por não ser acompanhada de dispositivos de organização do pluralismo e, em muitas vezes, sido bem recebida pelo fato de permitir a expressão de novos objetos sociais, cuja demanda aos poderes públicos não seriam suficientemente canalizadas nas associações tradicionais.

Mas, evitando ênfases enganosas, deve-se notar primeiramente que o regime diferenciado assegurado através da promoção pelo legislador foi baseado no modelo de apoio eventual, atribuindo relevância aos fins visados, ora para as formas de atividades, ora para as características organizacionais da associação ${ }^{167}$. O modelo premiado que opera essencialmente em favor dos objetivos fortes do pluralismo sem que sejam previstas formas de ligação ou organismos comuns entre as associações que operam no mesmo setor ou em áreas afins, com o risco de se encaminhar para um regime promocional que impulsione as associações a cuidarem essencialmente na defesa de áreas de privilégios ou canais de participação reservada ${ }^{168}$.

Por outro lado, não devemos subestimar o risco que o regime especial assegurado, em especial ao associacionismo privado não-especulativos (os chamados non-profit) podem se tornar um pretexto para incentivar, sempre e portanto, qualquer iniciativa que reivindica motivada por fins não-especulativo ${ }^{169}$. Significativo sob o ponto do silêncio é o tratado que se refere apenas à sociedade comercial, excluindo expressamente da disciplina comunitária a sociedade que não tem intenção de lucro no seu escopo (art. 48, ex art. 58). É precisamente esta lacuna que sugere uma necessária definição dos requisitos estruturais para a concessão dos benefícios, a fim de impedir que os operadores econômicos, dissimulando a lucratividade das suas empresas, possam se beneficiar dos incentivos assegurados aos non-profit. Tal exigência, parece, em parte responder ao modelo introduzido pela lei sobre o trabalho voluntário, que atribui relevância aos requisitos estruturais e de capacidades operacionais, que permitam as organizações selecionadas de estimular contratos com entes públicos para integrar as ações destes ou combinados com os mesmos na realização dos serviços sociais ${ }^{170}$.

O quadro regulamentar em matéria de objetos operando sem fins lucrativos foi então desenvolvido com a lei que rege as cooperativas sociais

\footnotetext{
${ }^{166}$ V. GEMMA, Costituzione ed Associazioni: dalla libertà alla promozione, Milano 1993; RIGANO, La Libertà Assistita, Padova 1995.

${ }^{167}$ V. RIDOLA, Diritti di Liberti, cit., 93.

${ }^{168}$ V. RIDOLA, op. cit.

169 V. RIGANO, Le Associazioni non Lucrative a confronto con la Disciplina Comunitaria del Mercato, in Giur. cost., 1997, 3548.

${ }^{170}$ V., em particular, art. 1 , § $1^{\circ}, 3,7$ e 8 Lei no $266 / 1991$.
} 
(Lei $n^{\circ}$ 381/1991) - precedida pela lei sobre as organizações não governamentais para a cooperação (Lei $n^{\circ}$ 49/1987) e seguida, entre as disciplinas da categoria de "organizações sem fins lucrativos de utilidade social"171, bem como veremos em seguida, pelo quadro da Lei sobre Serviços Sociais (Lei $n^{\circ} 328 / 2000$ ) - e parece se completar com a disciplina das Associações de Promoção Social (Lei de 07 de dezembro de 2000, $n^{\circ} 383$ ). A Lei 383/2000, dispõe sobre o reconhecimento e a disciplina da constituição das associações de promoção social, estabelecendo os princípios por regiões e por províncias autônomas deverão seguir nas disciplinas relacionadas entre as instituições públicas e as referidas associações.

Em particular, de acordo com o estabelecido no art. $1^{\circ}$, § 10, da Lei $n^{\circ}$ $383 / 2000$, a República reconhece o valor do associacionismo livremente constituído e sua multiplicidade de atividades, como expressão de solidariedade, participação e pluralismo, na promoção do desenvolvimento em todas as suas localizações geográficas, na salvaguarda de sua autonomia; favorecendo na sua contribuição original para a realização dos objetivos de caráter social, civil, cultural e de pesquisa ética e espiritual. Por outro lado, o parágrafo $3^{\circ}$ afirma que a presente lei tem também o objetivo de favorecer a formação de novas associações e de consolidar e fortalecer as já existentes que correspondam aos objetivos disposto no presente artigo.

São consideradas associações de promoção social as associações reconhecidas e as que não são reconhecidas, os movimentos, os grupos e as coordenações ou federações constituídas com o fim de realizar atividade de utilidade social a favor dos associados ou de terceiro, sem a finalidade de lucro e no pleno respeito pela liberdade e pela dignidade dos associados ${ }^{172}$, excluem-se, expressamente, as abrangidas nas categorias dos partidos políticos, as organizações sindicais, as associações patronais, as associações profissionais e de categorias, e todas as associações que têm como objetivo a tutela exclusiva dos interesses econômicos dos membros; são também excluídos os círculos privados e as organizações que colocam limitações no que diz respeito às condições econômicas dos seus membros ou discriminam a admissão dos mesmos.

No estatuto das associações de promoções sociais deve ser expressamente previsto não só a ausência de fins lucrativos, como a distribuição dos ganhos entre os associados, mas, também, a obrigação de reinvestir eventual excedente, em favor das atividades institucionais estatutariamente previstas.

Importante foi, também, a instituição, no departamento para negócios sociais da Presidência do Conselho de Ministros, de um registro nacional de associações de promoções sociais em nível nacional e de outros registros regionais e provinciais, com referência específica à regulamentação do

\footnotetext{
${ }^{171}$ Os chamados ONLUS, Decreto-lei 460/1997.

${ }^{172}$ Artigo 2, seção 1, a Lei no 383/2000.
} 
Ministro para a Solidariedade Social e da Autoridade Legislativa Regional para a definição acerca dos registros de trabalhos. A inscrição não constitui uma obrigação para as associações, mas é uma condição necessária para a conclusão de acordos com os entes públicos e para usufruir dos benefícios previstos em lei.

Em particular, as autoridades públicas podem celebrar acordos com as associações de promoção social inscritas nos registrados por pelo menos seis meses, com o desenvolvimento da atividade prevista no estatuto para terceiros, sem prejuízo, contudo, a verificação da pontual prestação prevista. Entre as facilidades devem ser mencionadas: o direito para os membros das associações de usufruírem de forma flexibilizada em relação ao tempo de trabalho, a fim de realizar atividades institucionais, a previsão da forma de retenção e de dedutibilidade sobre aqueles que fazem doações em dinheiro para as associações de promoção social inscritas no registro, e a possibilidade que os entes locais deliberem reduções sob os tributos de própria competência para essas associações; a previsão de formas de acesso para facilitar o crédito e de privilégio sobre bens móveis de devedores, bem como de facilitação de acesso aos financiamentos comunitários, especialmente o Fundo Social Europeu.

Digno de nota, por fim, a instituição de um observatório nacional de associações ${ }^{173}$ presidido pelo Ministro da Solidariedade Social, e composto por 26 membros (representantes de associações e especialistas), com sede no Departamento para Assuntos Sociais. No mesmo Departamento foi instituído um fundo para financiar projetos específicos de suporte econômico ao associacionismo. O Observatório Nacional vale-se da colaboração do ISTA ${ }^{174}$ e do Observatório Nacional para o Voluntariado, e junto com esse último, designa dez membros do $\mathrm{CNEL}^{175}$. As regiões também criaram os seus próprios observatórios regionais.

As intervenções legislativas que sumariamente descrevem a inserção em um mais amplo contexto preveem a participação das mencionadas pessoas associadas, juntamente com as autoridades públicas, na realização de sistema integrado de intervenções e de serviços sociais ${ }^{176}$. A própria Lei 328/2000 prevê mecanismos para apoiar os entes públicos para associações que atuam no terceiro setor ${ }^{177}$, propondo uma resposta para a demanda da tutela e da promoção do voluntariado que se origina da participação da natureza dos

\footnotetext{
173 Art. 11, Lei no 383/2000.

${ }^{174}$ Istituto Nacionale di Statistica.

${ }^{175}$ Consiglio Nacionale Economia e Lavoro.

176 Artigo $1^{\circ}$, parágrafo 50, Lei n 328/2000: "a gestão e a oferta dos serviços públicos serão prestadas pelos entes públicos, bem como por entidades interessadas na concepção e implementação de ações, organizações sem fins lucrativos de utilidade social, organismos de cooperação, organizações voluntárias, associações e instituições para a promoção social, fundações, entidades de proteção e outras entidades privadas".

${ }^{177}$ Ver, em particular, art. 11.
} 
direitos fundamentais, instância dialética destinada a superar os limites atomísticos da liberdade social ${ }^{178}$.

Segundo o Tribunal Constitucional, o voluntariado constitui a expressão mais imediata da vocação social primitiva do homem e a mais direta relação do princípio da solidariedade social, e, portanto, deve ser objeto de tutela e da promoção no plano legislativo, não só, deve ser tutelado de modo uniforme em todo o território nacional, pelo menos em relação à conotação essencial das atividades e das organizações que operam nesta área, bem como para ordenar a definição do tipo de relação que deve existir entre as várias instâncias dos poderes públicos e as organizações de voluntariado, e em ordem das relativas modalidades das ações administrativas ${ }^{179}$.

No entanto, questiona-se, hoje, a compatibilidade da disciplina estatal sobre o cumprimento voluntário para o novo conjunto de responsabilidades entre Estado e as regiões delineadas pela Lei Constitucional $n^{\circ} 3 / 2001$, a qual, dentre outras, reconheceu às regiões o poder legislativo em relação a todas as matérias não expressamente reservadas à lei do Estado ${ }^{180}$, invertendo a lógica da enumeração de assuntos de competência regional endossados pelo art. 117, em sua formulação original. É possível, hoje, reviver um título constitucional de legitimidade da intervenção estatal descrita em termos de voluntariado? Para a doutrina mais atenta ${ }^{181}$, hipoteticamente, há, pelo menos, três soluções para as questões ora postas a seguir, que me limito a expor sinteticamente.

A primeira solução poderia ser aquela de acreditar que as disposições da Lei $n^{\circ} 328 / 2000$ configuram-se como norma padrão, destinada a sobreviver com base no princípio da continuidade - até o momento em que as regiões providenciem com lei própria a disciplina da matéria ${ }^{182}$.

Uma segunda solução poderia alavancar o poder de legislar exclusivo, reconhecido ao Estado, para determinar o nível básico de benefícios relacionados com os direitos civis e sociais que deve ser garantido em todo o território nacional ${ }^{183}$, que o Tribunal Constitucional considerou não como uma matéria em sentido estrito, porém do mesmo modo de uma competência do legislador estadual idôneo, para investir em todos as matérias, em relação as quais o legislador mesmo deu poderes para estabelecer regras necessárias

\footnotetext{
${ }^{178}$ Tribunal Constitucional, Sentença no 75/1992.

${ }^{179}$ Acórdão no 75/1992.

${ }^{180}$ V. a atual formulação do art. $117, \S 4^{\circ}$.

${ }^{181}$ E. ROSSI, Introduzione al Convegno, in E. Rossi-P. CARROZZA, Sussidiarietà e Politiche Sociali dopo la Riforma del Titolo V della Costituzione, Atti del Convegno svoltosi a Pisa il 27 e 28 settembre 2002, a cura di E. A. Ferioli, Torino 2004, 11 ss.

${ }^{182}$ E. Rossi, op. cit., 14.s.; v., ora, art. $1^{\circ}$, § $2^{\circ}$ da Lei $n^{\circ} 131 / 2003$, que, adotando a orientação expressa pelo Tribunal Constitucional - por exemplo, nas Sentenças $n^{\text {os }} 422$ e 510/2002, 196 e 197/2003 - estabeleceu as disposições normativas estatais vigentes na data da entrada em vigor da presente lei em matérias pertencentes à legislação regional continua a ser aplicável, em cada região, até a data de entrada em vigor das disposições regionais da matéria.

${ }^{183}$ Artigo 117 , § $2^{\circ}$, letra "m".
} 
para assegurar a todos, dentro do território nacional, o gozo de benefícios garantidos, como conteúdo essencial de tais direitos, sem que a legislação regional possa limitar-Ihe ou condicionar-Ihe ${ }^{184}$. Mas, como apontado até mesmo por Rossi ${ }^{185}$, a adesão a esta solução deixa em aberto outra questão: considerando que a Lei $n^{0} 328 / 2000$, além de indicar os níveis essenciais, estabeleceu as modalidades com as quais os níveis essenciais das prestações concernentes aos direitos sociais, devem estar definidos pela chamada previsão da letra "m", deve entender-se, exclusivamente, como vínculo relativo ao conteúdo da prestação, ou pode (deve) considerar também a modalidade de individualização do fornecimento de tais prestações?

Uma primeira resposta a esta interrogação foi dada pelo mesmo Tribunal Constitucional, em relação as competências que trata a letra "m", do $\S 2^{\circ}$ do artigo 117 da Constituição, que dispõe as mesmas atribuições ao legislador estatal um fundamental instrumento para garantir a manutenção de uma adequada uniformidade de tratamento no plano do direito de todos os indivíduos, por um sistema caracterizado por um nível de autonomia regional e local, considerando um significativo acréscimo que as fortes consequências da incidência sobre o exercício das funções atribuídas a competência legislativa e administrativas das regiões e das províncias autônomas impõe, evidentemente, que essas escolhas, pelo menos em suas linhas gerais, sejam feitas pelo Estado com lei, que também irá determinar os procedimentos adequados e precisos por ações formais para prosseguir as especificações e as articulações adicionais que serão necessários nos diversos setores $^{186}$.

A última solução hipotética altera, no entanto, para a individualização na lei de diretrizes, na qual as disposições são colocadas em estreita correlação/ atuação aos princípios constitucionais (...), para estimar que, em quanto tal, exige uma unidade de fundo na disciplina legislativa, incluindo regional ${ }^{187}$. Trata-se, provavelmente, de retomar a argumentação da Sentença nº75/1992, sobre a necessidade de uma regulamentação estatal que garantisse um desenvolvimento do voluntariado o mais possível uniforme em todo o território nacional, que naquela ocasião levou a considerar os princípios da lei de diretrizes sobre o voluntariado, da mesma forma dos princípios gerais do ordenamento jurídico.

Atualmente, além dos dados emergentes do direito positivo e da problemática relativa à compatibilidade das intervenções legislativa do Estado com o novo conjunto de competências resultantes da atual redação do artigo 117 da Constituição, o elemento do qual não parece poder prescindir é o estabelecimento de canais de cooperação entre o público e o privado,

\footnotetext{
${ }^{184}$ Sentença n ${ }^{\circ}$ 282/2002.

185 Op. cit., 15 s.

186 Sentença n 88/2003.

${ }^{187}$ V. novamente E. Rossi, op. alt. cit., 16.
} 
inserindo nos mesmos grupos sociais as estruturas de participação e formas de procedimento ${ }^{188}$. Nesta perspectiva, propõe-se de seguir, ainda no que se refere às associações, o surgimento da doutrina acerca da individualização do ponto de equilíbrio entre a demanda de prestação e a oferta de colaboração, no desempenho das competências públicas, oriundos de grupos sociais, nas dimensões processuais (status activus processualis) das liberdades fundamentais ${ }^{189}$. A ampliação da gama de ações da liberdade de associação, feita através da participação de grupos sociais sobre as decisões dos aparatos públicos, permitiria de fato a comparação entre diferentes visões de interesse público, e desenvolveria diferentes perspectivas de atualização dos valores constitucionais ${ }^{190}$.

Além disso, a citada dimensão processual poderia contribuir para conter a privatização do Estado social, do movimento sem limites à sociedade do compromisso de cuidado e proteção social abrangido na esfera pública. A privatização do Estado social, que é apenas parte de um fenômeno maior marcado pela perda da centralidade do Estado relacionados com os processos, inter-relacionados, de integração européia e de globalização da economia. A esse mais amplo fenômeno parece ter conduzido a mesma proliferação das autoridades independentes que levaram a uma crescente importância nos setores fundamentais, tais como aqueles nos mercados financeiros ou o rádio e televisão, contribuindo para o desgaste gradual do Estado centralizador que realiza as tarefas de regulação e de supervisão, substituindo-o (em quanto autônomo e independente, ainda público) em lidar com várias categorias de usuários envolvidos, para se tornar a expressão imediata da autonomia dos assuntos sociais.

A chamada dimensão processual da liberdade associativa, no entanto, parece apenas parcialmente desenvolvida no ordenamento italiano, sobretudo no que se refere à resolução dos conflitos através dos procedimentos. Pensa-se atentamente invertendo aos institutos de participação na lei sobre ordenamento da autonomia local (Lei 142/1990), que recai a disciplina específica aos estatutos e regulamentos locais. Em particular, o artigo $6^{\circ}$ da citada lei, sobre a afirmação do princípio da necessária intervenção das partes interessadas nos procedimentos suscetíveis de incidência relativas e trata sobre situações jurídicas subjetivas, atribui-se às comunidades a tarefa de valorizar a forma associativa livre e de promoção de organismos de participação dos cidadãos pela administração local, mesmo em um bairro ou distrito.

Resultando assim, na precursão, em nível local, de alguns dos conteúdos da Lei 241/1990, que estabelece as "regras do procedimento administrativo e acesso aos documentos administrativos", e em particular a previsão para indivíduo, portador de interesse público ou privado, bem como os portadores

\footnotetext{
${ }^{188}$ RIDOLA, Diritti di Libertà, cit., 96 ss.

189 HÄBERLE, Le Libertà Fondamentali nello Stato Costituzionale, Roma 1993, 202 ss.

190 Assim RIDOLA, op. alt. cit., 97.
} 
de interesse difusos constituídos em associações ou comitês, suscetível de prejuízo pela medida, têm a faculdade de intervir no processo "(art. $\left.9^{\circ}\right)$, e, entre as pessoas legitimada a intervir, nos termos do mesmo art. $9^{\circ}$ da Lei $n^{\circ} 241 / 1990$, estão também as associações de promoção social (art. 27, Lei $n^{\circ} 383 / 2000$ ). De tal modo, estendeu o modelo que permite às associações envolvidas na resolução de conflitos através de procedimentos, defendida na lei que institui o Ministério do Meio Ambiente (Lei $n^{\circ}$ 349/1986) que reconheceu em favor de associações ambientalistas a legitimidade para denunciar os fatos lesivos de bens ambientais dos quais tiverem ciência e intervir nos processos de dano ambiental e de recorrer em sede de jurisdição administrativa para anulação de atos ilegítimos (artigo 18 , $\S 4^{\circ}$ e $5^{\circ}$ ). Legitimação que resulta contudo, limitada às associações de proteção ambiental reconhecidos pelo Ministério do Meio Ambiente e identificadas com base nas finalidades programáticas e o ordenamento interno democrático prevista no estatuto, bem como na continuidade das ações e da sua relevância externa" (art. 13).

A legitimidade da promoção da ação judicial e da intervenção de processos propostos por terceiros, igualmente com finalidade de ressarcimento de danos decorrentes de interesses coletivos, são reconhecidos às associações de promoção social, em relação aos objetivos gerais pretendidos. Além disso, soma-se a legitimação de recorrer em sede de jurisdição administrativa para a anulação de atos ilegítimos lesivos aos coletivos relativos às finalidades perseguidas pelas associações de promoção social (art. 27 da Lei no 383/2000).

Não se pode deixar de referir, contudo, que a valorização do papel das associações como atores na defesa dos interesses difusos e coletivos e como sujeitos de participação na vida pública não corresponda a um adequado desenvolvimento de outros elementos fundamentais da dimensão processual da liberdade associativa, que deve ser alcançada na inserção das associações em uma comunicação pública que os previna do confronto com outras experiências sociais ${ }^{191}$.

Em conclusão, devem ser elaboradas as previsões do artigo 118, último parágrafo da Constituição, como resultado da revisão feita pelo art. $4^{\circ}$ da Lei Constitucional $n^{\circ} 3 / 2001$ : Estado, regiões, cidade metropolitanas, províncias e comunidades devem promover a iniciativa dos cidadãos, individualmente e associados, para o desenvolvimento da atividade de interesse geral, com base no princípio da subsidiariedade, com esta previsão incluída no texto constitucional da chamada subsidiariedade horizontal, que já havia sido reconhecida de forma diferente na legislação ordinária ${ }^{192}$.

De acordo com a definição que parece preferível, o disposto no último parágrafo do artigo 118 é de aplicação imediata, mesmo a espera de posteriores especificações ou jurisprudência, de como caberá aos cidadãos assumirem a

${ }^{191}$ RIDOLA, op.cit., 97.

${ }^{192}$ V., em particular o artigo $4^{\circ}$ da Lei no $59 / 1997$ e art. $3^{\circ}$, parágrafo $5^{\circ}$ da Lei no 267/2000. 
iniciativa autônoma de interesse geral que constitua o núcleo essencial da disposição ${ }^{193}$.

Em essência, a novidade contida na chamada previsão constitucional consiste no fato de o privado poder agir, autonomamente, no interesse geral, sem esperar as autorizações ou requisitá-las ao poder público, pelos fatos em que os cidadãos podem realizá-las, e que a autoridade pública não pode limitá-los, apenas observá-los passivamente as suas atividades, nem pode obstaculizá-los ${ }^{194}$. Os reflexos dessa previsão sobre o mundo do associacionismo parecem evidentes, ao ponto que foi considerado que a representação de milhares de cidadãos e suas organizações têm o reconhecimento constitucional da atividade já desenvolvida há décadas, constituindo para esses setores da sociedade italiana, ao mesmo tempo uma legitimidade, um fundamental ponto de chegada, mas também um ponto de partida, um estímulo para continuar nas suas iniciativas no interesse geral ${ }^{195}$.

\section{REFERÊNCIAS BIBLIOGRÁFICAS}

\section{Sobre as diversas problemáticas da liberdade de reunião:}

BARILE P. Assembramento, in enc. Dir., III, Milano 1958.

BORRELLO R. Riunione (diritto di), in enc. Dir., XL, Milano 1989.

CARETTI P. I Diritti Fondamentali, Torino 2002.

D'ALESSIO R. Sub art. 17, in Commentario Breve alla Costituzione, a Cura di Crisafulli e Paladin, Padova 1990.

GARDINO CARLI. Riunione (liberta di), in Dig. disc. Pubbl, XIII, Torino 1997.

GIOCOLI NACCI. Libertà di Riunione, in Trattato di dir. Amm., diretto da G. Santaniello, XII, Padova 1990.

MEZZANOTTE C. La Riunione nella Dinamica del Fenomeno Associativo e come Valore Costituzionale «autonomo», in Giur cost., 1970.

MINGUZZI. La Teoria dell'opinione Pubblica nello Stato Costituzionale, Bologna 1887.

MUSSO. Brevi note sulla Libertti di Riunione in Italia ira la fine dell'ottocento e l'inizio del novecento, in scritti in onore di C. Mortati, I, Milano 1977.

PACE A. La Libertà di Riunione nella Costituzione Italiana, Milano 1967.

. La Libertà di Riunione, in la Pubblica Sicurezza, a cura di Barile, Vicenza 1967.

. Sub art 17, in Commentario Cost. Branca, Bologna-Roma 1977.

. Problematica delle Libertâ Costituzionali, Parte speciale, II ed., Padova 1992.

Violazione della «liberal sociale» o, piuttosto, restrizzat' irrazionale della libertà individuale, in Giur. Cost., 1998.

PIUSCO. Riunione (liberal di), in enc. Giur, XXVII, Roma 1991.

193 ARENA, II Principio di Sussidiarietà Orizzontale nell'art. 118., u.c. della Costituzione, Al Convegno Cittadini attivi per una Nuova Amministrazione, realizado em Roma 7-8 fevereiro 2003, p. 3 do documento.

${ }_{194}$ Assim, ARENA, op. cit., 28.

${ }^{195}$ ARENA, op. cit., 3s. 
RANELLETTI. La Polizia di Sicurenza, in primo Trattato completo di Diritto Amministrativo Italiano, direto da V.E. Orlando, IV, I, Milano 1904.

RIDOLA P. Nuovi Orientamenti della Giurisprudenza della Corte Costituzionale in Tema di Liberta di Riunione, in Giur.. Cost., 1979.

Sobre as diversas problemáticas da liberdade de associação, também com referência ao princípio pluralista e da autonomia das formações sociais:

BALDASSARRE A. Libertà, I) Problemi Generali. in Enc. giur., XIX, Roma 1990.

BARBERA A. Sub art. 2, in comm. Cost. Branca, Bologna-Roma 1975.

BARBIERI-CONTENTO-GIOCOLI NACCI. Le Associazioni Segrete, Napoli 1984.

BARILE P. Associazione (diritto di), in enc. Dir., di, Milano 1958.

BARTOLE. Problemi Costituzionali della Libertà di Associazione, Milano 1970.

BASILE M. L'intervento dei Giudici nelle Associazioni, Milano 1975.

BRUNELLI G. Struttura e Limiti del Diritto di Associazione Politica, Milano 1991.

CAMMARATA. I/ Concetto del Diritto e la Pluralia degli Ordinamenti Giuridici (1926), ora in id., Formalismo e Sapere Giuridico, Milano 1963.

CARETTI P. I Diritti Fondamentali, Torino 2002.

CESARINI SFORZA. La Teoria degli Ordinamenti Giuridici e il Diritto Sportivo, in foro it., 1933.

CHELI E. Libertà di Associazione e Poteri di Polizia: profili storici, in la pubblica sicurezza, a cura di Barile, Vicenza 1967.

CRISAFULLI V. Associazioni (diritto civile), in Nss. Dig. It., I, Torino 1939.

CUOMO G. Le Associazioni Segrete e fart. 18 della Costituzione, in scritti in onore di v. Crisafulli, II, Padova 1985.

DE SIERVO U. Associazione (libertà di), in Dig. Disc. Pubbl., I, Torino 1987.

ESPOSITO C. Lo Stato Fascista e le Associazioni, li, Padova 1934.

GALGANO F. Delle Associazioni non Riconosciute e dci Comitati, in comm. Cod. Civ. Scialoja-branca, Bologna 1976.

GEMMA. Costituzione ed Associazioni: dalla libertà alla promozione, Milano 1993.

GIANNINI M. S. Sulla Pluralith degli Ordinamenti Giuridici, Roma 1950.

HABERLE P. Le Liberta Fondamentali nello Stato Costituzionale, Roma 1993.

LAVAGNA C. Istituzioni di Diritto Pubblico, V ed., Torino 1981.

LEONDINI. Associazioni Private di Interesse Generale e Libertà di Associazione, i, profilico-Stituzionalistici, Padova 1998, e II, Profili Amministrativistici, Padova 1999.

MAZZIOTTI DI CELSO M. Lezioni di Diritto Costituzionale, II, Milano 1985.

MELONCELLI. Associazioni Segrete e Diritti d'associazione, in Democrazia e Diritto, 1981.

MODUGNO F. Pluralità degli Ordinamenti, in enc. Dir., xxxiv, Milano 1985, ora in Id Legge .- ordinamento giuridico - pluralità degli ordinamenti, Milano 1985.

MORTATI C. La Persona, lo Stato e le Comunità Intermedie, Roma 1959. . Istituzioni di Diritto Pubblico, II, Padova 1976. 
PACE A. Sul Limite della Polizia dello Spettacolo e sulla Diversa Garanzia Costituzionale dei fini delle Riunioni e delle Associazioni, in Giur. Cost., 1967. . Sub art. 18, in comm. Cost. Branca, Bologna-Roma 1977. . Problematica delle Libertà Costituzionali, parte spedale, fled., Padova 1992.

PALADIN L. Diritto Costituzionale, III ed., Padova 1998.

PATRONO M. La Libertà di Associazione: una legge di attuazione costituzionale, in legalità e giustizia, 1993, ora in la Repubblica di Icaro, Roma 1995.

PETTA. Le Associazioni Anticostituzionali nell'ordinamento Italiano, in giur. Cost., 1973.

RESCIGNO G. U. Corso di Diritto Pubblico, 1v ed. Riveduta, Bologna 1996.

RESCIGNO P. Persona e Comunità, Bologna 1966.

RIDOLA, Ancora in tema di Libertà Negativa di Associazione, in giur. Cost., 1987. . Democrazia pluralistica e libertà associative, Milano 1987. . Associazione Le Libertà di Associazione, in enc. Giur., III, Roma 1988. . Sub art. 18, in Commentario Breve alla Costituzione, a Cura di Crisafulli e

$\overline{\text { Paladin, Padova } 1990 .}$ . Diritti di Libertà e Costituzionalismo, Torino 1997.

RIGANO. La Libertà Assistita, Padova 1995.

. Le Associazioni non Lucrative a confronto con la Disczolina Comunitaria del Mercato, in giur. Cost., 1997.

ROMANO SANTI. L'ordinamento Giuridico (1918), II ed., 1946, rist., Firenze 1951.

ROSSI E. Le Formazioni Sociali nella Costituzione Italiana, Padova 1989.

SICA V. Le Associazioni nella Costituzione Italiana, Napoli 1957.

VASSALLI F. Propaganda Sovversiva e Sentimento Nazionale, in Giur. Cost., 1966. 